Österreichische Akademie der Wissenschaften / Austrian Academy of Sciences AAS WORKING PAPERS IN SOCIAL ANTHROPOLOGY Volume 35

\author{
Carol Yong Ooi Lin \\ DAMS DISPLACEMENT AND \\ RESETTLEMENT OF INDIGENOUS \\ PEOPLES IN MALAYSIA: \\ GENDER INSIGHTS AND LESSONS \\ FROM SOME CASE STUDIES
}

Edited by

Claudia Aufschnaiter

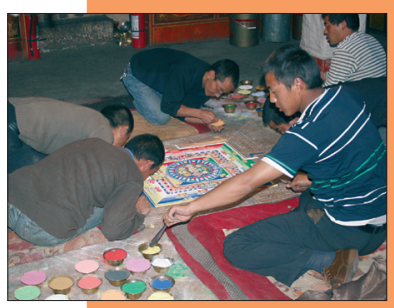

Band 35 


\section{AAS Working Papers in Social Anthropology / \\ ÖAW Arbeitspapiere zur Sozialanthropologie}

ISBN-Online: 978-3-7001-8467-6

DOI: $10.1553 /$ wpsa35

Wien 2019

Editors / Herausgeber:

Andre Gingrich \& Guntram Hazod

Special issue editor:

Claudia Aufschnaiter

(C) Institut für Sozialanthropologie

Österreichische Akademie der Wissenschaften

Hollandstraße 11-13

A-1020 Wien

Fax: 01/ 51581-6450

E-Mail: sozialanthropologie@oeaw.ac.at 


\title{
DAMS DISPLACEMENT AND RESETTLEMENT \\ OF INDIGENOUS PEOPLES IN MALAYSIA: \\ GENDER INSIGHTS AND LESSONS FROM SOME CASE STUDIES *
}

\author{
CAROL Yong OOI LiN
}

\begin{abstract}
What has gender to do with dams displacement and resettlement? The late social anthropologist Elizabeth Colson through her long-term ethnographic research since the 1950s on forced uprooting by development projects with the Gwembe Tonga of Zambia saw the importance to link gender with the experiences of uprooted women, men and children (cf. Colson 1971, 1999). Yet, in practice, gender continues to be overlooked in many dams and resettlement schemes everywhere. This paper critically reviews issues of dam-induced displacement and resettlement of indigenous communities in Malaysia from a gender lens. It begins by examining resettlement of dam-displaced indigenous communities in Malaysia, particularly in my research areas, to highlight gendered and social consequences, and linkages with ancestral land rights and access to resources. The next section then examines issues of compensation, resettlement and rehabilitation processes. It concludes with gender insights and lessons from my case studies on dam decisions and resettlement processes. The paper argues that dam displacement and resettlement issues are highly gendered, and frequently associated with top-down decisions that seek to legitimise land acquisition of indigenous peoples' lands in the name of "development". I thus call on decision makers and implementers to adopt a more responsible and gender-responsive approach to "development".
\end{abstract}

Keywords: dams; displacement; gender; indigenous peoples; land acquisition; Malaysia; resettlement and rehabilitation, Sarawak, Sabah.

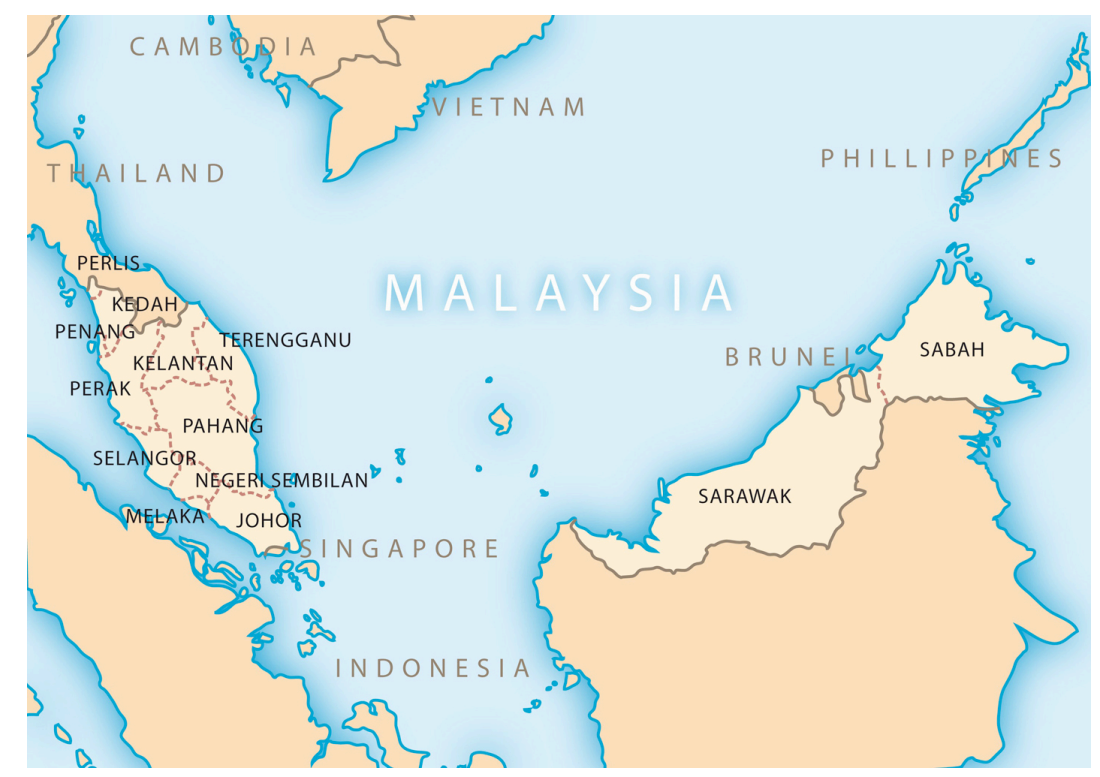

Fig. 1.

General map of Malaysia.

\footnotetext{
* This paper is based on a talk presented in the framework of the ISA Regional Guest Lectures at the Institute for Social Anthropology, Austrian Academy of Sciences, Vienna, 18 October 2018. I wish to thank Claudia Aufschnaiter and her colleagues for the invitation. My particular thanks go to Andreas Burghofer for his valuable comments and suggestions, and to the editors of the present series.
} 


\section{Introduction}

This paper highlights the vulnerability of indigenous peoples in Malaysia, in particular women who are displaced from their homes and lands and relocated elsewhere. Due to the need to clear forests and divert the river, dams can effectively deprive those in the way of dams of rights to their traditional resources.

The construction of dams everywhere continues to arouse controversies and conflicts. This is despite the known benefits of dams that include hydropower generation, water supply, irrigation, flood control, drought alleviation, navigation, recreation and tourism (Scudder 2005: 5-6). Dams have forcibly displaced and relocated millions of women, men and children. ${ }^{1}$ Large dams have displaced an estimated 40-80 million people between 1950 and 1990 (WCD 2000: 104). These figures increased substantively after 1990 with the construction of dams then not counted. Resettled populations are worse off than before (Cernea 2000; Oliver-Smith 2009; Scudder 2005; WRM 2003). The ecological and environmental impacts of dams and economic costs of projects are worrying (Goldsmith and Hildyard 1984; INSAN 1996; McCully 1996). Dams submerge land, homes, farms and precious irreplaceable wildlife and flora in the way of the project. Dams have been the most direct and irreversible modifiers of river flows, expropriated land, are associated with forest destruction and loss of livelihood resources (Ghai 1994; Howitt et al. 1996; Yong various years), and sometimes even the use of force or violence and the loss of human lives (Colson 1971, 1999; Fernandez and Thukral 1989; Ideal Times 1999; McCully 1996; Morse and Berger 1992; SUARAM 1999; SUHAKAM 2009; WFP 1996). In her study of the Gwembe Valley Tonga people in southern Zambia uprooted by the Kariba Dam in the 1950s, Colson (1971: 3) documented eight villagers killed and 32 wounded in collusion with the police when they rioted and refused to make way for the dam. Thukral (1992) aptly calls large dams "rivers of sorrow" because of the hardship and impoverishment of the people affected indirectly or directly.

It is claimed that dams have made an important and significant contribution to human development (WCD 2000). Yet, the experiences of dam affected peoples (my case studies and others) and extensive documentation both by non-governmental organisations (NGOs) and scholars reveal a long list of negative implications of dams, uprootedness and forced resettlement. Anthropology's tradition of detailed long-term study of communities undergoing dam-induced uprooting and resettlement is best represented in the pioneering work of Elizabeth Colson and Thayer Scudder. Beginning in the mid-1950s, both anthropologists carried out "before and after" studies of the resettlement of the peoples living in the Gwembe Valley in Zambia and Zimbabwe, the large majority of whom were Gwembe, and the Tonga Valley, to make way for the Kariba Hydroelectric Dam on the Zambezi River (Colson 1971, 1999, 2003; Scudder 2005). Colson's work was a major ground-breaking longitudinal ethnographic study of people undergoing relocation in connection with dam construction. "The best resettlement case study"

\footnotetext{
${ }^{1}$ Dams are a major cause of displacement but not the only one. People are also displaced by mining, wars and conflicts, urbanisation and infrastructure projects such as highways, industrial complexes, airports, nuclear plants, pipeline projects, military bases, and the notification and expansion of reserved forest areas, sanctuaries and parks.

2 There were, however, earlier works on rural-to-urban migration and 'detribalisation' in Africa during precolonial and colonial times, and extractive industries such as copper mining in the copper belt of Broken Hill (now Zambia), Rhodesia (Zimbabwe) and Lesotho. This body of work was done under the auspices of the Rhodes-Livingstone Institute (now the Institute for African Studies of the University of Zambia).
} 
showed how dam-induced displacement "often leaves the majority worse off" (Scudder 1993, 2005). Partridge (1989: 374) describes Colson's work as "the most comprehensive and systematic work - although not the first such study - on social consequences of involuntary resettlement.” On general anthropological approaches, see Cernea and Guggenheim 1993.

Clearly, also, indigenous peoples and ethnic/tribal minorities who traditionally occupy areas around forests and rivers tend to be the prime targets of eviction (Brody 2002; McCully 1996; Scudder 2005; WCD 2000; Yong 2003, 2006). Scudder's (2005: 56-86) comparative survey of dam-induced resettlement in 50 cases using statistical analysis revealed at least half of the cases (54\%) involved the resettlement of indigenous or tribal people and other ethnic minorities.

The uprooting through displacement irrevocably alters the pre-existing framework of land rights and resources for indigenous peoples and ethnic minorities - the base foundation of indigenous identity, culture, social systems and political structures (Yong and Wee 2015; Yong 2003, 2006). As Brody (2002: xiv) writes:

Indigenous peoples for the most part live in poverty and endure a sense of profound cultural and spiritual loss, watching their resources, the homes of their gods - be they forests, mountains, fish or the earth itself - being used to make others wealthy [...]. Alongside losses of land are parallel losses to other sources of well-being: languages, belief systems, links between generations and self-respect.

The impacts on gender ${ }^{3}$ are often not considered in dam displacement, compensation, resettlement and rehabilitation policies and implementation (ADB 2003). In many studies too, attention is primarily on either the technical or socio-economic aspects. Yet there is great variation and adaptive capacity of women/girls and men/boys to deal with resettlement impacts, change and continuity/discontinuity in their lives (Colson 1999; Guggenheim 1993; Koenig 1995; Sikka 2014; Srinivasan 1997; Yong 2003 and 2006). Colson's analysis of the heterogeneity of the displaced Gwembe women and men in phases of change and continuity emphasises this point. According to Indra (1999), Colson "pushes the bounds of research convention in several ways to construct representations of Gwembe Tonga women and men as complex actors in history, multiply constrained by gender, age, locality, and national policy." The "next generation" anthropologist Lisa Cliggert studying the Gwembe Tonga displaced by the Kariba Dam - inspired by Elizabeth Colson's and Thayer Scudder's pioneering work - has also noted the gender factor in household and kinship gender relations and power dynamics between women and men, and their children, although gender is not the only factor (Cliggert 2001, 2010).

I argue that within indigenous groups uprooted and resettled because of dams, it is women, children and poorer households who bear the brunt. Sikka's (2014) study of "the case of missing toilets" in Sardar Sarovar Dam resettlements in Vadodara, Gujarat (India), for example, clearly showed how indigenous peoples, minorities and tribal communities suffered from gender and racial prejudice and discrimination, and that they were denied the full recognition of their rights. According to Sikka, "Dalit and Adivasi households are much less likely to have a toilet on the premises" because of their very low position in the hierarchy of Indian citizenship,

\footnotetext{
${ }^{3}$ On the concept on gender, I refer to feminist definitions: Gender as a powerful social and cultural construct that relates to a set of power relations intersecting all aspects of life and categories of people $(\mathrm{Ng}$ 1994, 1999). Gender not only determines the way women and men relate to each other, but also governs how society - the state, the family, the market - assigns power, roles, responsibilities, resources, and rights to women and men (Kabeer 1994; Moore 1988; Ng 1999; Whitehead 1984).
} 
noting that the "[p]rovision of toilets $[\ldots]$ is not merely about efficiency in service delivery - it is deeply political." In Africa, Colson's (1971 and 1999) study of the Kariba Dam found that displaced Gwembe women suffered physical violence, bad marriages, and lowered status, among other social consequences of resettlement. My own research on dam-displacement in Malaysia too shows that the effects of resettlement differ for women and men (see below).

Another core argument in this paper is that most large dams involving forced relocation of the people to be impacted by the decision, or desire, to build a dam are not consulted from the outset. In fact, they are usually the last to know about the impending project. In Malaysia, as elsewhere, it is a familiar story. The centrally driven "decision-making" by the state and other powerful vested interests (sponsors, developers, etc.) to implement dam projects that displace and resettle those in the way is justified as a prerequisite for advancing the "development" agenda. This echoes common experiences of other similarly affected groups elsewhere. A case in point are Adivasi or tribal peoples in India, often ignored in state planning and development policies and decisions. Yet they are historically one of the most adversely affected by displacement due to infrastructure projects such as large dams and mines (Fernandes and Thukral 1989).

Following this, the next section examines resettlement of dam-displaced indigenous communities in Malaysia, particularly in the areas of my research, to highlight gendered and social consequences, and linkages with ancestral land rights and access to resources. The paper then interrogates the missing gender links in issues of compensation, resettlement and rehabilitation processes. The concluding section provides insights and lessons from a gender perspective from my case studies on dam decisions and resettlement processes.

\section{Background and Context}

\subsection{The People}

In Malaysia, a country of approximately 32.4 million inhabitants, indigenous peoples comprise $13.8 \%$ of the national population (Department of Statistics, Malaysia 2018). The dominant population groups are the Malays, Chinese and Indians, along with some other smaller groups.

Orang Asli, a Malay term which translates as "original peoples" or "first peoples", are the indigenous minority peoples in Peninsular Malaysia and known to be the descendants of the earliest inhabitants in the Malaysian peninsular. For administrative purposes they are officially classified into three main groups - Negrito (Semang), Aboriginal Malay (Proto Malay) and Senoi - and further divided into 18 ethno-linguistic sub-groups. ${ }^{4}$ The smallest group are the Negrito, while the Senoi are the largest in number, followed by the Proto Malay.

Sarawak is the largest of the 13 states of Malaysia followed by Sabah - they are located on the island of Borneo and form East Malaysia. In Sarawak the indigenous peoples are known as Dayak and Orang Ulu. In Sabah they are called Anak Negeri Sabah. There are 37 different indigenous groups and sub-groups throughout Sarawak, with the largest being the Iban. Within the 39 indigenous groups and sub-groups in Sabah the largest group are the Kadazandusun.

\footnotetext{
${ }^{4}$ Categories of Orang Asli groups and sub-groups in Peninsular Malaysia:

- Negrito (Semang): Kintak, Lanoh, Kensiu, Jahai, Mendriq and Batek

- Aboriginal Malay: Orang Selatar, Jakun, Orang Kuala/Laut, Orang Kanaq, Temuan and Semelai

- Senoi: Temiar, Semai, Mah Meri, Che Wong, Jah Hut, Semaq Beri and Temoq
} 
The various indigenous peoples have their own languages, ways of life, cultural traditions, social structures, traditional leadership and local wisdom, and other distinct characteristics that are clearly different from the ethnic Malays and the rest of the national population. Bumiputera means "son of the soil" in Malay, a label the Malaysian government uses for the Malays and the indigenous peoples of Malaysia to distinguish them from the "others", the non-native ethnic Chinese, Indians, etc. The majority of the indigenous peoples prefer to refer to themselves as Orang Asal ("original peoples"), which they coined at a workshop on indigenous land rights in 1996.

The indigenous peoples in Malaysia share one thing in common: a close collective physical, cultural and spiritual relation to and use of their traditional lands and ancestral forests. Land and forests give life and meaning to their whole being; it is in the land that their history, identity and ways of life are contained. Indigenous peoples in Malaysia also share common problems related to the acquisition of indigenous lands and exploitation of their natural resources, issues which I will discuss subsequently in the context of dam displacement and forced resettlement.

\subsection{Researcher and Methods}

I have studied dams and resettlement in Malaysia since the mid-1980s, alongside my wider social activism work with civil society groups, poor marginalised communities, and indigenous women, men and children. As a researcher and activist I have written extensively on the situation of the marginalised and indigenous peoples of Malaysia, particularly women and girls, examining issues of land rights, resources and livelihood rights, gender-based violence, and "development" policies that affect them. This paper is based on research for my master's (1997) and doctoral (2006) theses on gender, displacement and resettlement of indigenous peoples in Sabah and Peninsular Malaysia respectively, in the context of dams through different times and across various geographical regions. Fieldwork was conducted in one resettlement site in Sabah and three resettlement sites in Peninsular Malaysia (see section 2.3 below). My primary methods in data gathering were ethnographic fieldwork, participant observation and archival research as well as quantitative and qualitative surveys that included interviews and focus group discussions. The paper also draws on a wealth of empirical data available from personal experience as a long-standing activist and researcher.

\subsection{Description and Location of the Dam Projects and Resettlement Sites}

\subsubsection{The Temenggor Dam and Air Banun Resettlement Scheme, Upper Perak, Peninsular Malaysia}

The 127-metre high Temenggor Dam, located in the Temenggor-Belum forests of Upper Perak, about $300 \mathrm{~km}$ north of the capital city of Kuala Lumpur, was constructed in the early 1970s for electric power generation. The dam inundated an area covering 15,200 hectares, including the houses of 266 families with approximately 1,058 individuals from 13 indigenous Orang Asli communities, ${ }^{5}$ mainly the Jahai $(64 \%)$ and Temiar (34.5\%), with a minority of Lanoh and Semai (Itam Wali 1993). The affected 13 communities were relocated to the Air Banun resettlement scheme in Upper Perak in 1979, where they had no land or productive resources, for instance in the form of forests. The scheme is located about $60 \mathrm{~km}$ from the Upper Perak district capital,

\footnotetext{
${ }^{5}$ The Temenggor dam also affected 124 Malay families, resettled separately from the Orang Asli, to an easily-accessed village called Air Ganda in Gerik. However, this is not within the scope of this paper.
} 
Gerik. It contains 15 villages - for the original 13 communities and two breakaway communities. Some villages are accessible by car, some only by 4 -wheel drive and the remote ones are reachable only by foot.

It is important to note that this was not the first time that the Jahai were forcibly resettled. In the 1950s, the dispersed Jahai and other Orang Asli communities in the Temenggor-Belum forests were regrouped and resettled into "jungle forts", as a military strategy of the British colonial government to isolate them from members of the Communist Party of Malaya (CPM) in the jungle (PRO Kew 1952; The Straits Budget 3, December 1953, p. 7). Later, the Malaysian government replaced the "jungle forts" with "regroupment" schemes, which involved grouping together dispersed Orang Asli settlements in forests around the central Titiwangsa mountain range into larger units and resettling them into areas selected by a federal agency for development of Orang Asli (Malay: Jabatan Kemajuan Orang Asli, JAKOA).

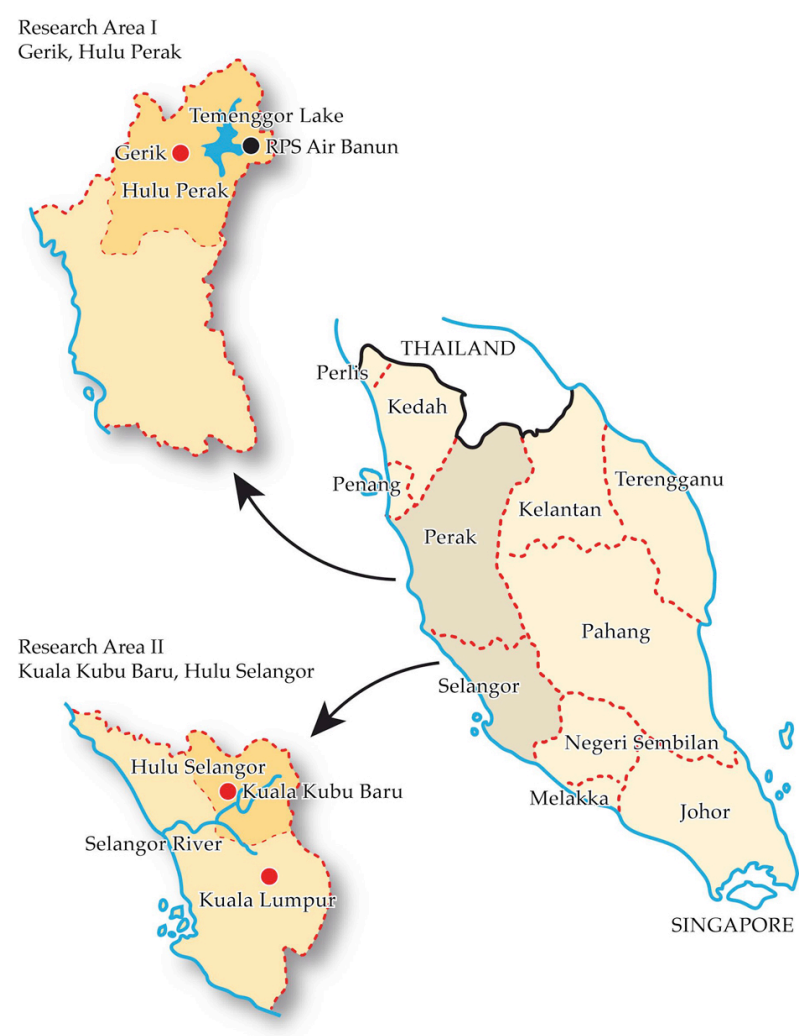

Fig. 2. Research sites in Temenggor Dam (Perak) and Sungai Selangor Dam (Selangor) areas.

Various facilities were provided by the government such as houses, a nursery, a health centre, the JAKOA administration centre, a playground, a Muslim prayer place (surau) and a small farming plot. Ostensibly for modernising the "backward" and "poor" Orang Asli communities (Jimin 1978; Jimin et al 1983), the purpose of resettling Orang Asli was similar to that at the time of the British colonial administration - to cut Orang Asli ties with communists at the Malaysian-Thai border.

The 13 Orang Asli communities mentioned above were relocated to the Pulau Tujuh Resettlement Scheme. At that time, in 1972, the government began work to construct the Temenggor Dam as a strategy to further hinder the access routes of the communist guerrillas operating from the forest bases around the central Titiwangsa mountain range. As the dam also flooded the Pulau Tujuh site, the 13 communities were forcibly relocated to the present site at Air Banun in 1979.

\subsubsection{The Sungai Selangor Dam and Resettlement of Kampong Peretak and Kampong Ger- achi, Kuala Kubu Bharu, Selangor}

The Sungai Selangor Dam is situated downstream of the confluence of Sungai (Sg.) Selangor and Sg. Gerachi, and approximately $5 \mathrm{~km}$ east of the township of Kuala Kubu Bharu in the state of Selangor, Peninsular Malaysia (see fig. 2). Selangor, with Kuala Lumpur within its boundary, is the most developed state in Malaysia. The 110-metre high dam was constructed from 
1999 to 2003, to satisfy the domestic and industrial water demands in Selangor and surrounding industrial and resident areas.

The dam flooded 600 hectares of land and two Orang Asli Temuan villages, Kg. Gerachi and Kg. Peretak. Kg. Gerachi was fully submerged by the dam and Kg. Peretak in part. Altogether they numbered approximately 339 people; 160 in $\mathrm{Kg}$. Gerachi (41 families) and 179 in $\mathrm{Kg}$. Peretak (43 families). The total recognised land area of Kg. Gerachi and Kg. Peretak was about 400 hectares and 168 hectares respectively.

In August 2001, the affected families in Kg. Gerachi were resettled to the new village situated on a hill adjoining the western side of the Selangor Dam's reservoir. Called Kg. Gerachi Baru, it is located about $20 \mathrm{~km}$ further from the old village, and an additional $2.6 \mathrm{~km}$ off the main road. It is not easy to go up to the new Gerachi village by conventional means of transport, more so on foot, since it is now situated approximately 300 metres higher, as compared to a few minutes' walk to the old village, which was located on the banks of the Selangor River. The resettlement of the 43 families of $\mathrm{Kg}$. Peretak was undertaken in October 2001. This new village site is $6 \mathrm{~km}$ upstream on $\mathrm{Sg}$. Selangor and easily accessed. The people retained its old name, Kg. Peretak, since this new village was pushed some 50 metres back from its original site on the banks of the Luit River, a tributary of the Selangor River.

\subsubsection{The Babagon Dam and the Resettlement of Kampong Tampasak, Sabah}

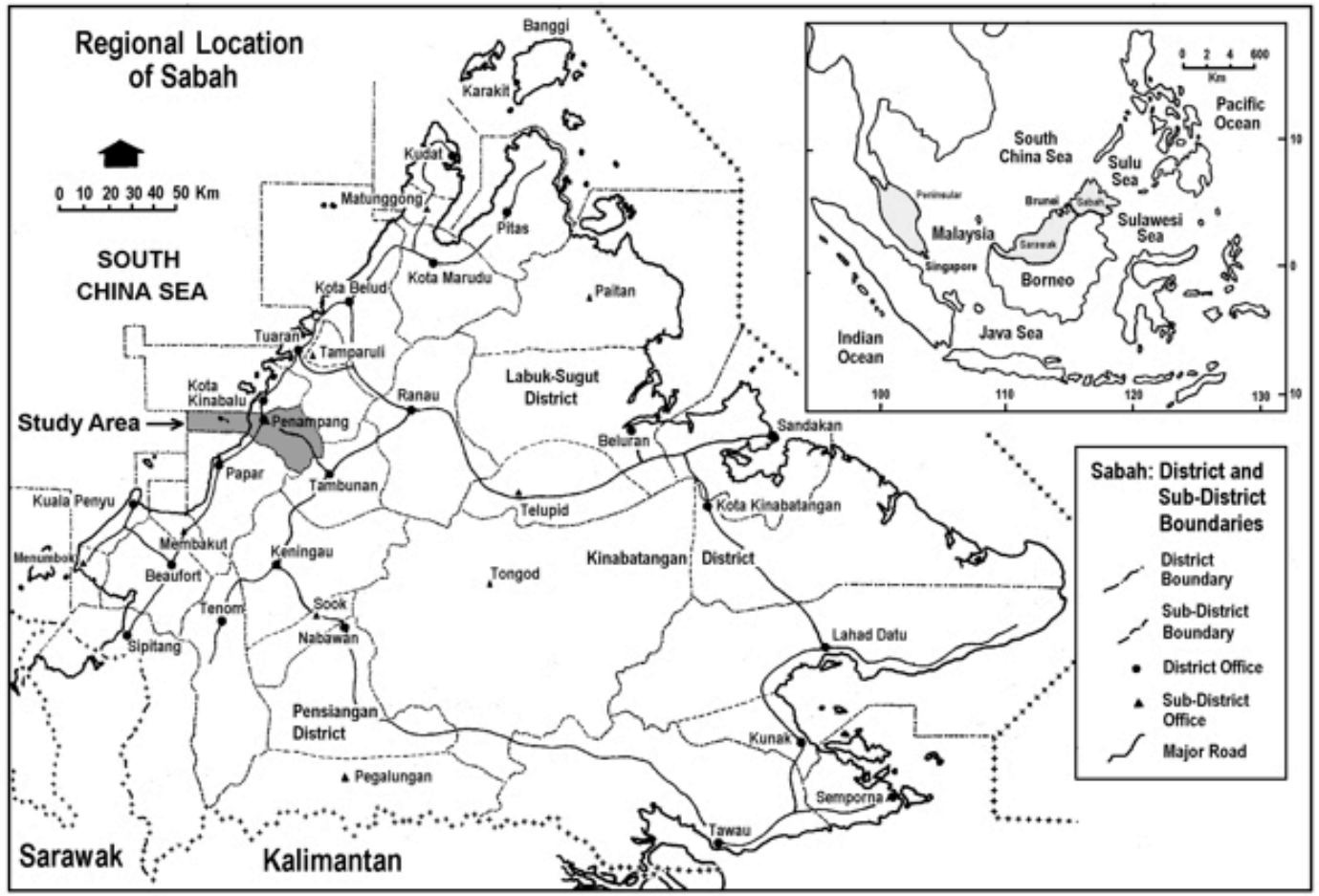

Fig. 3. Location of Sabah, showing study area (Babagon Dam and resettlement of Kampong Tampasak).

The 70-metre high Babagon Dam is located on the Babagon-Tampasak River, in western Sabah. This dam was part of a large project, as part of which the Sabah state government in 1992 awarded to a private company, Jetama, the exclusive rights to supply water to the state capital, Kota Kinabalu, and surrounding areas on the west coast for a concession period of 20 years. Besides the Sabah government (20\% stake), the other shareholders of the privatisation joint- 
venture were Hume (Sabah) Sdn. Bhd. (35\%), Suez Lyonnaise des Eaux (35\%), and John Holland (M) Sdn. Bhd. (10\%).

The Sabah state government expropriated some 169,860 hectares of land to make way for the dam. Four indigenous Kadazandusun villages were affected, but only one village, Kg. Tampasak, was entirely submerged by the dam. The Tampasak residents, notably women, supported by other nearby communities and civil society groups protested peacefully in meetings and demonstrations against the dam project but were essentially ignored. The 200-odd residents of Kg. Tampasak were evicted in stages between February 1994 and February 1995. Some families were forced to evacuate their old village area under an ultimatum order. The evictees were resettled in a new village situated on the fringes of their old village. The new resettlement area is located approximately $30 \mathrm{~km}$ by road from Kota Kinabalu city and is accessible by vehicle.

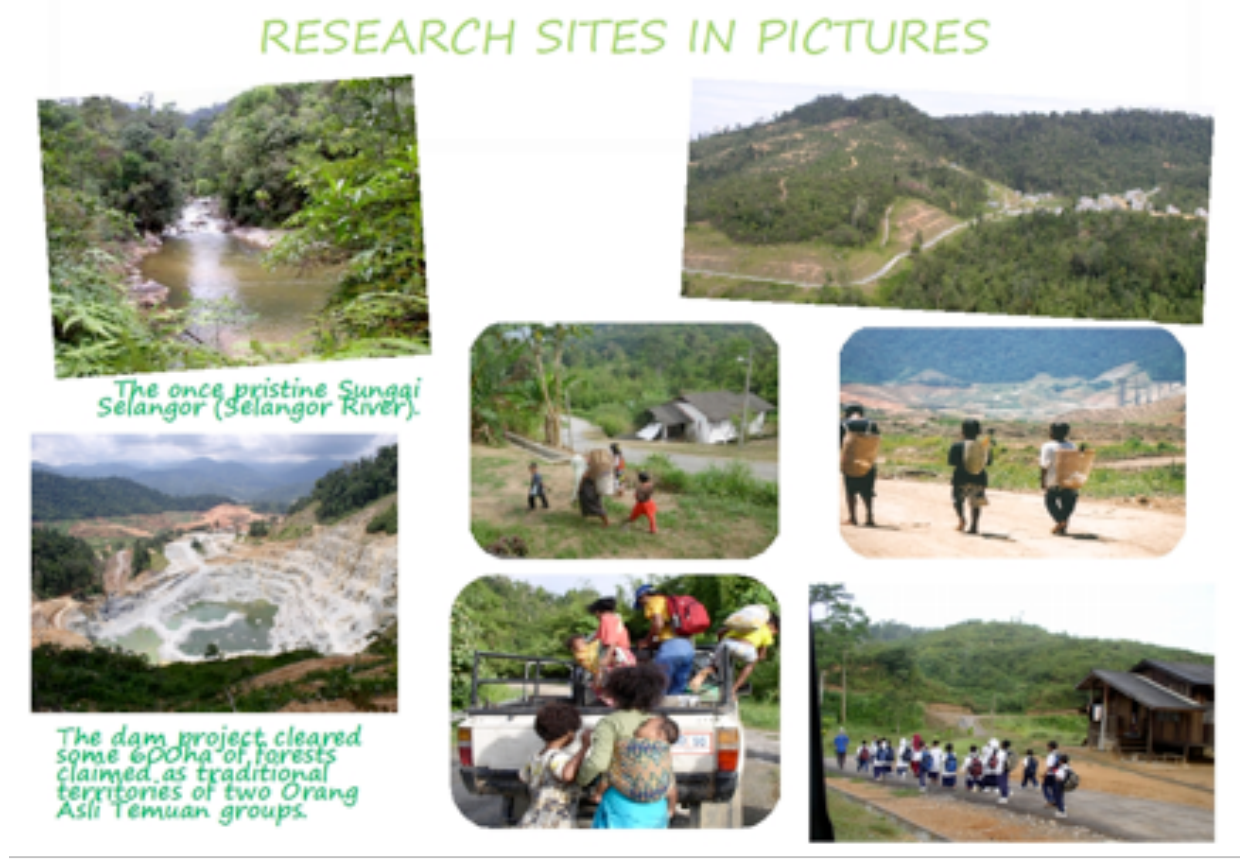

Fig. 4.

Top right:

Kampong Gerachi adjacent to a hillside palm oil plantation. Middle row:

Kampong Peretak (left) and Temuan boys returning from community forest degraded by the dam construction (right).

Bottom right: Villagers' transport, and children with their guide walking to the primary school about $1 \mathrm{~km}$ from their village of Air Banun Regroupment Scheme, Perak. (Photos: C. Yong)

\section{Locating Gender in Dam Resettlement of Indigenous Peoples in Malaysia}

Usually it is assumed, particularly by the state and elites in the dam business, that dams in the current "development" framework are for the improvement of the general welfare of the population, as well as for water and hydro power development to cater to human needs (Him Dhara 2011; Pearce 1992). Harnessing rivers and water resources are also meant to bring socioeconomic development to the poorest and remotest regions within the country, for example as claimed for the ADB funded Yudongxia Reservoir in Guizhou Provice, China (Sapkota and Ferguson 2017). Or hydropower is sold as "clean, efficient and environmentally friendly" in times of "climate change crisis", for instance hydropower projects in India and Himachal Pradesh that are also ADB funded (Him Dhara 2011).

Malaysia follows this path of development, touting dams as "engines" of economic progress, development, science and technological advancement to modernise and industrialise. The construction of the biggest dam in Malaysia, the Bakun Dam in Sarawak was largely to meet in- 
creasing demands from the cities and large, energy-intense industries such as aluminium smelter (INSAN 1996). In neighbouring Sabah, the state government recently proposed a dam project as a solution to meet water shortage, particularly due to burgeoning cities and the tourism industry, despite objections from villagers threatened with displacement (Malaysiakini 2018). There are plans to build more dams throughout Malaysia, including Sarawak's "green energy" power projects to generate electricity (http://www.theborneopost.com/2014/01/20/). More dams mean higher demands for land, and displacing people from their homes and land. The "benefits" for the people asked to sacrifice for the "common good" (Roy 1999) or "good of the nation" (Kothari 1994) include, among others, alleviating poverty, losses well compensated, improved roads and facilities in the new settlements, and jobs and other opportunities.

But this is rarely the case for the dam-affected indigenous peoples in Malaysia, as elsewhere. For a broad picture of the projects globally and impacts, see McCully 1996; Scudder 2005; WDC 2000. Firstly, dams inevitably involve displacement of people and land acquisition, despite local protests or resistance (Yong 2003). Secondly, large dams have high social and environmental costs as opposed to benefits (Goldsmith and Hildyard 1984), notably "serious impacts on the lives, livelihoods, cultures and spiritual existence of indigenous and tribal peoples" (WCD 2000: 110), while often violating the human rights of the displaced communities (Fernandes 1999; Him Dhara 2011; KHRP 2005). Especially with regard to indigenous peoples, and tribal/ethnic minorities, issues pertaining to human rights, land tenure, resource access, participation, and free, prior and informed consent of indigenous peoples in dam policy and decisions remain contested (Carino 1999; Colchester 1999; IRN 2005; WCD 2000).

Moreover, and importantly, gender has not been at the forefront of the debates, planning and implementation of dam projects, including resettlement and rehabilitation, in Malaysia (Yong 2003, 2017). This paper therefore focuses on gender and human rights considerations as they pertain to dam-displaced peoples and resettlement outcomes, and examines these issues by looking at various cases studies I have researched.

In the following section, I therefore deal with questions of gender in connection with compulsory land acquisition, resource access, livelihoods, power structures, family and community life before and after resettlement of indigenous communities affected by dams in Malaysia. I also seek to show that there are common experiences with other dam-affected groups around the world, despite differences in regions, histories, cultures, and the character of the dams.

\subsection{Compulsory Land Acquisition and Gendered Effects}

Under the Malaysian federal constitution, land, forest and water resources are a state matter and the individual states have the power to seize land for "development" and "public purposes". In Sabah, for instance, the state government used the Land Acquisition Ordinance to expropriate Kg. Tampasak for the Babagon dam to supply water for the "larger good". Here, the state government over-rode and did not recognise customary rights as practised under adat, where land is passed down from one generation to the next, and is critical for livelihoods. Out of 28 women and 49 men of the Tampasak Kadazandusun community I interviewed, 17 women (61\%) and 32 men $(65 \%)$ owned land that was untitled; of these, $88 \%$ of women and $78 \%$ of men had their lands compulsorily appropriated for the Babagon Dam without compensation or undercompensated. The negative effect on women was greater, as they tended to use those lands for 
subsistence and rural income from crops such as rubber and tobacco, which they sold at the local markets.

Case studies analysed in the handbook on Gender, Forestry and Livelihoods (Griffen 2001), which includes specific studies on dam-induced resettlement and deforestation impacts (Yong 2001), showed major changes in livelihoods and gender relations resulting from women's loss of access to and control over forest resources. In a study of the Batang Ai Dam, the first dam built in Sarawak in 1981 that led to the resettling of over 3,000 Iban indigenous peoples, Hew and Kedit (1987) and $\mathrm{Ng}$ (1999) found that the women were more likely to lose their traditional land rights and less likely to receive compensation or replacement land, which went to the men. In the context of disasters and resettlement, it was also found that women and female-headed households suffered more than men (Enarson and Morrow 1998; Yong, Siahaan and Burghofer 2015a).

Several major dams in Peninsular Malaysia flooded river basins, and invariably caused the resettlement of affected indigenous Orang Asli because the areas where most of the Orang Asli are found are naturally resource-rich areas. Such displacements have resulted in not only the loss of traditional territories and forest rights of the Orang Asli but were also primarily responsible for deforestation and forest degradation (Yong 2006, 2006a). Similarly, the Bakun Hydropower Project, which promised economic development for Sarawak, resulted in the loss of ancestral land of over 10,000 indigenous peoples, who were forcibly relocated. They lost hunting grounds, access to wild game, rivers and other vital forest resources, particularly valuable timber harvested from the catchment area, totalling over 70,000 hectares (SUARAM 1999).

Various studies have shown that indigenous peoples, tribals and ethnic minorities worldwide form a majority of those displaced from lands and livelihoods by dam projects. They often received little or no compensation and, as a consequence, were reduced to poverty and destitution (Colchester 1999; Fernandes 1998; McCully 1996; Scudder 2005; Thukral 1992; WCD 2000). This is the case for India's Hirakud Dam, where approx. 180,000 people were deprived of their land. However, official records state only 110,000 displaced people. 70,000 mostly tribal, Dalit and 'other backward class' people were not recognised as displaced persons under the Land Acquisition Act, which only provides for individual ownership and not tribal peoples' mostly commonly owned land and forests (Pattanaik, Das and Misra 1987).

The dam list goes on, among others: Brazil's Tucuri Dam, Egypt's Aswan Dam, Ghana's Akosombo Dam, Guatemala's Chixoy Dam, Indonesia's Cirata and Kedung Ombo Dams, Mali's Manantali Dam, Laos' Nam Theun2 Dam, the Lesotho Highlands Water Project, and the Kaptai Hydropower Dam in the Chittagong Hill Tracts in south-east Bangladesh (McCully 1996; Scudder 2005). In Central America, the proposed El Diquís Dam electricity generation, located about $5 \mathrm{~km}$ from the Teribe community, the indigenous peoples of the Térraba territory in the Buenos Aires region of southern Costa Rica, will flood more than $10 \%$ of the traditional land of the Teribe people (HRC 2010). This is a grave threat to the survival of the Teribe as a people, since they number around only 750 individuals, or a mere $1 \%$ of Costa Rica's total population.

Indigenous peoples and societies have long been a central field of study in anthropology, especially the interconnectedness of indigenous peoples and lands, in defining the meaning of their lives, origins, histories, identities, cultural practices, customs, kinship and institutions (der Sluys 1992). In the context of large dams and displacement, land acquisition and dispossession 
extinguish indigenous peoples' rights to customary land, respected and guarded across generations. It also threatens their distinct cultural identities closely associated with land and natural resources. Unlike in other "development" projects, in dam projects the losses are irreversible. Land, homes and other property submerged by dams cannot be returned to their original condition. The displaced people are physically uprooted and then 'transplanted' to another area, into another community's land (Yong and Wee 2015). This leads to a range of adverse effects on the resettled as well as the host community.

Within indigenous groups, indigenous women are doubly discriminated against by virtue of their indigenous status and their gender (Bag 2017: 38). Gender and gender perspectives remain weak in issues of land acquisition and involuntary resettlement impacts, for example, the dispossession of land and impacts on traditional land rights in indigenous communities (Kusakabe 2017). To understand why compulsory land acquisition is traumatic for rural indigenous peoples within the larger context of dam displacement in Malaysia, it is important to understand customary land rights and tenure systems, the role of adat (customary law) in the regulation of such rights, and what land means to both women and men, beyond the typical notion that farmers are mostly "men" and women their dependents.

Adat traditionally recognises the rights of indigenous women and girls to access, inherit and use customary land and family resources. But women's rights and access to and control of productive resources, including land, are often mediated by men - fathers, husbands and male community leaders, principally through inheritance, joint family ownership, marriage and marital residence. Wanyeki (2003: 26) observed a similar situation for sub-Saharan African women: "Customary law does allow for women's access to land. However, such access is gender-based and dependent upon customary marriage and inheritance norms."

In $\mathrm{Kg}$. Peretak, one of my fieldwork sites, I found at least 18 cases of women who owned communal land through family inheritance and marriage. In the adjacent $\mathrm{Kg}$. Gerachi two elderly Temuan said that by cultivating a given plot of land, on her own or with family members, the community recognised women's rights to use and control it. Sometimes women had to deal with men to get a better deal within the family, sometimes not, depending on how they were valued both as wives and as daughters and sisters, which varies from family to family. Like the Temuan women, Jahai women in the Temenggor Dam area in Gerik had no direct involvement in negotiating the boundaries of specific territorial space for dwelling, hunting or foraging (Jahai: tek asal and tek ye), but they could use and access space as freely as the men. The dominance of men exists in many indigenous cultures, but because adat was stronger in the pre-dam period, women's informal rights to access land continued to be recognised by the family and community.

Over time, the state introduced modern land tenure systems based on individual land titles. Many indigenous communities affected by "development" projects experienced difficulties in asserting their claims to communal lands. The dam-affected indigenous communities that I studied all experienced difficulties in this regard. Likewise, indigenous women's collective rights to ancestral lands safeguarded under adat were ignored or worse, eroded, resulting from compulsory acquisition of communal lands.

Women's access to customary land was further restricted by stereotyped notions that the public or formal sphere is the preserve of men, including land registration processes and titles, so state land entitlements and other privileges went to men, who tended to pass them on to sons or other male relatives. Thus, women's access to land and security of tenure under customary law, 
which are considered secondary rights since they are mediated in gendered ways, tended to be very insecure (Hilhorst 2000: 182). To compare, in Sri Lanka, for instance, male control over land was more pronounced after the Mahaweli Dam was built. There the prevailing law that allowed women to co-own and control land in her own right was undermined by a new arrangement to accord rights to the household to nominate the heir, which usually favoured a son (Agarwal 1996).

As said earlier, many indigenous women and girls are dependent on their relationship with a man (father, husband, male relative) to access land, rather than in their own right. Male bias assumes that men, as heads of households, control and manage land, through which access and opportunities for the family are channelled (Agarwal 1996; Jackson 2003; Razavi 2003; Wanyeki 2003). This gender bias is largely responsible for eroding indigenous women's preexisting customary rights and access to land and forest under adat, changing gender roles and weakening women's status in the family and social spheres. The gender and patriarchal bias of the state and within indigenous society combine to marginalise indigenous women's rights relating to land and other entitlements recognised under adat law, as my case studies showed.

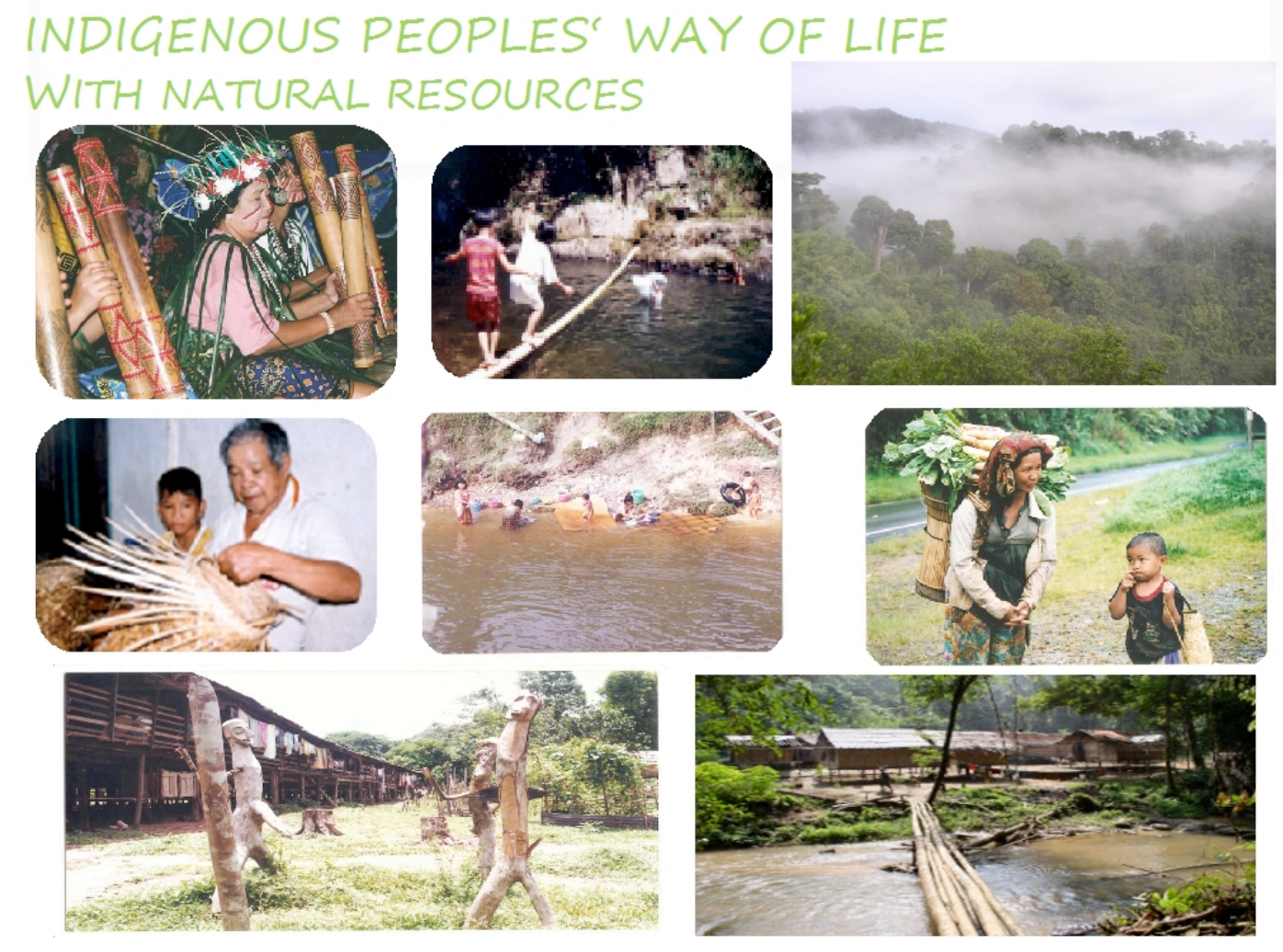

Fig. 5. The acquisition of indigenous lands deprived indigenous peoples of their access to natural resources and means of livelihood. (Photos: C. Yong) 


\subsection{Resource Use, Livelihoods and Gender Relations}

Rural people tend to have the capacity to change modes of production and other aspects of their way of life (Scudder and Habarad 1991:180). Indigenous peoples in Malaysia are subject to changes even without displacement and resettlement, but changes are accelerated or exacerbated when imposed on the communities through dominant values ascribed to land claims and property (cf. Cernea 2004; Cernea and McDowell 2000). Over the decades, many indigenous communities have seen their rights steadily eroded by the state using legislation to acquire their land and its resources for "development" (dam projects), which made their lives much harder.

Changed resource bases can have profound effects on a community, on individual and group habitats, resource sovereignty, resource management and livelihoods systems. The impacts differ for women and men (gender differences) but there are also differences based on age, status, vulnerability and local context, for example.

\subsubsection{Effects of Resource Depletion on Community Livelihoods and Gendered Impacts}

Scarcity and degraded natural resources are not only the result of dams but also of encroachment by migrant settlers and logging, which contribute to continuing threats to subsistence and forest-based cash-income activities (cf. Gadgil and Guha 1995; Guha 2013). Women interviewed in my research became even more marginalised as their access to productive resources was reduced. For example, the Jahai women and children who once had access to Temenggor Lake could now only fish in the nearby small muddy creek after their resettlement to Air Banun. Men, however, could continue fishing as some of them owned motorised boats to reach the farther side of the lake to fish.

Moreover, the fact that gravel roads connected the Air Banun resettlement to the main trunk road benefitted mostly the few men with personal vehicles, who sold rattan and fish to middlemen and buyers outside. This was hardly the case before. Before, both women and men in the village directly sold fish to middlemen. As a Jahai woman in Banun said, "Now the men go fishing alone or with others at the farther end of the lake, and then to town to sell the catch. We women have to stay at home to look after the house and our children." Koenig (2002) found that women displaced from the Kibale reserve in Uganda and finally resettled experienced increased stress because they no longer had individual gardens to provide food for their families. Several studies have also noted reductions in fish catches and fishing activities among damdisplaced communities elsewhere, such as the Kainji Dam on the Niger in West Africa, Kariba Dam on the Zambezi and Akosombo Dam on the Volta Lake (Adams 2001: 215-249).

Denial of access rights to roam forests in the vicinity of the dam for traditional activities such as foraging, hunting and trapping has adverse effects on livelihoods and hunting and gathering skills. Lim's (1997) study of Orang Asli in eight villages in Perak and Pahang alludes to Orang Asli's dependence, to varying degrees, on the forest for their livelihood and as an income resource. The relationship between Orang Asli today and the forest, according to Lim, was disrupted by land regroupment and resettlement schemes (like Air Banun, one of my research sites), reducing their dependence on the forest for livelihood and forcing them to seek alternatives in non-forest-related activities and wage work. $\mathrm{Ng}$ (1999) identifies a similar trend among the resettled Ibans of Batang Ai Dam in Sarawak where the drastic decline of many sources of subsistence production forced people to increasingly depend on purchased items for survival, 
and in turn the need to make money. Before, when food ran out, they went fishing or went into the forest to collect edibles or harvest fruits to overcome food shortage.

Resettlement, and indirect causes such as the state islamisation programme among the Orang Asli including prohibitions in terms of food etc., affect the livelihood and lives of indigenous peoples previously rich in traditional economic resource bases. While I was one day with an elderly Jahai woman and her daughter weeding a little tobacco plot behind their house, the mother told me:

Life was different before regroupment. We had many places to look for food. It was strenuous roaming the forest, but at least we were assured of some food, even on unproductive days of hunting and searching for food. But now we must look for money to buy food. This new surrounding and religion has too many changes which affect us.

In the new settlement of $\mathrm{Kg}$. Tampasak, all the houses are accessible by vehicles as opposed to the old village where many houses could only be reached by walking. They also now live in houses with piped water from taps, and although there was frequent "water stoppage", several women said it had eased some household chores. In spite of this positive side, almost all women and men interviewed reported on the declining quality, accessibility and availability of natural resources as a result of being relocated and resettled outside of forest areas: forests for free water sources as well as the rich diversity of food, medicines, materials for shelter and other household items, to name a few. $50 \%$ of the women emphasised the loss of water due to the river being dammed, and $77 \%$ the loss of forests for craft materials. Men found it most difficult to collect rattan. Children lost their forest which was once their "living school" and playground. In another settlement area, a young mother said, "Prior to our resettlement to Kg. Gerachi Baru in 2001 to make way for the Selangor Dam, we lived on what we gathered from the forest and rivers. Now, we have to walk further to catch fish or collect edible shoots and petai [parkia speciosa]. Life is so much harder now." For unmarried single women, widows/widowers and the elderly, life was doubly harder after relocation, particularly those with few opportunities to earn cash and dependent on others to satisfy basic needs.

Family and community networks were important for women and men in a traditional land based economy: for exchange labour in farming and other economic activities, reciprocal labour-sharing (gotong royong) during peak agricultural seasons, borrowing of small amounts of food and other household items, and collective childcare services, to name a few examples. Some elderly women and men could use their age as agency to mobilise support from their children and relatives for daily survival in conditions of resource scarcity or depletion. Agency, kinship, generational and gender dynamics have been identified as key variables in family cooperation and conflicts in disasters and scarce resources situations, in several detailed long-term studies among Zambia's Gwembe Tonga (Colson 1960; Scudder and Colson 1982; Cliggert 2010, 2001). My fieldwork particularly among the Jahai in the remote settlement of Air Banun found that children frequently shared meals with their aged parents/grandparents although they lived in different houses in the settlement. Sharing of food and reciprocity was a common practice among kinship groups. But the practice was slowly disappearing, as more and more younger individuals sought jobs outside the village, or families became more self-centred in the face of resource scarcity. 


\subsubsection{Gender Relations, Gender Roles and Income Opportunities}

When traditional economic livelihoods change, the effects on the community and on women can take many forms. Today, many women in the villages of my research locations (Tampasak, Sabah; Gerachi and Peretak, Selangor; and Air Banun, Perak) said they stayed home to look after the children and house, after their resettlement. Women and girls in indigenous communities, as in most rural societies, are primarily responsible for not only daily household chores but also collecting water and firewood for household use (cf. Griffen 2001). Loss of local sources for water (streams, rivers, lakes) and fuel can be a burden on women and children. After resettlement, piped water supply and gas for fuel was available but the reproductive work of washing and cooking at home instead of at the river, were assigned to women and girls. Within the conventional notion of "public" labour and "private" household services, women assumed the household tasks (Harris 1981; Kabeer 1994; Whitehead 1984). This echoes the work of Thambiah (1997) among the Jakun, an Orang Asli subgroup, who argued that "the pervasive myth" of the man's sphere as public and the women's sphere as private has been used by the external dominant culture to justify the sexual division of labour among the Jakun, which is otherwise a sexually egalitarian society.

The need for cash to meet household and daily expenses have pushed particularly the adult women, younger girls and boys to work outside the village, especially those in Tampasak, Gerachi and Peretak with access to roads. In other words, after resettlement, more women are now in waged employment too to supplement family income. Thus the conventional notion of men as "household heads and providers" and "bread-winners" overemphasises displaced indigenous men's roles as primary household earners. As Moore (1988: 79) argues, "it is a naive argument to portray men inevitably as the winners and women as the losers" because this "distorts the complexity of the real nature of gender relations, obscures the agency of different women to respond to processes of social transformation and reinforces the treatment of women as a homogenous category."

In terms of the work that women and men take up, jobs are mainly menial: service jobs in the local town council as general sweepers and grass-cutters, in department stores and factories in cities, where women and youth with low education are hired. When I revisited Gerachi and Peretak villages in March 2018, parents told me that their grown-up children - who were in 2003 little girls and boys tagging along with me when I interviewed their parents - had landed in similar jobs as they had, e.g. harvesting bamboo/rattan or as cleaners and domestic helpers. Gender differences existed with respect to wages in informal sectors. Although the earnings of the labourers were quite low on the whole, women's daily wages were even lower, ${ }^{6}$ placing women in a subordinate position vis-à-vis men, by paying them lower wages and thereby undervaluing women's labour. Concerns of low-waged women labourers were relatively invisible, e.g. gender disparity in wages or sexual harassment at the workplace.

Some men migrated to find work in logging camps, as there were fewer jobs at the dam site after the dam was built. The women left behind had to maintain the households. There were also several families of single mothers. They were young women involved with outside male

\footnotetext{
${ }^{6}$ For example, in the oil palm plantations in Peretak and Gerachi, for work from 7:30am-12:30pm, women doing manuring, weeding and conservation work were paid RM15 a day, whereas the men received RM20 a day for planting, transport of the palm, work on culverts, clearing, etc., with a bit extra for both women and men for overtime work till 3pm (2003 rates).
} 
workers on the dam site, who had become pregnant and had later been abandoned by the fathers of their children. ${ }^{7}$ Female-headed households shouldered double burdens, earning to feed the family and running the household. In another sense, it gave women an agency of their own, and a degree of economic freedom and control over their lives and household. Women who earned could contribute to the family income, thus gained some bargaining power within the family on some decisions pertaining to daily food and child-minding.

Young women with children confined to the settlement areas did home-based work such as packaging factory products, for example, and could earn about RM3 packing 30 packets of biscuits. Some started small shops in the village. When I asked about their work, women responded, "We are not working". Children's labour was also unrecognised and unpaid. Children said, "We're just helping our parents", rather than being aware of being a child worker, legal or illegal. Housewives and home-based child workers were both not valued in a market economy because it was unremunerated.

$\mathrm{Kg}$. Gerachi and Kg. Peretak women with small children also said they preferred bamboo collecting to make colok at home. ${ }^{8}$ Usually family members with some free time also contributed labour. A 21-year-old single mother said, "We can earn some money from this. Quite large amounts of bamboo and rattan vines can still be found within distance in this area. We women have been collecting rattan and bamboo to earn money, even before we were resettled here. So we know how to do this work."

Women could sell the finished colok any time, and in lean times, they could get a cash advance from the buyer whom they had been dealing with directly for many years - a small but significant power for women to exercise control over their lives. Men who previously collected gaharu (aloes wood) and rattan for cash income were now also more involved in colok-making, due to gaharu getting scarce and rattan now a restricted item and needing a harvesting licence under state legislation that was difficult for ordinary Orang Asli to obtain.

Like the Tampasak homeworkers, the Temuan women (and men) in the colok industry remained invisible in the formal production economy. The prevailing sexist ideology saw them merely as "housewives who just happened to be using their time in a profitable way". Within this notion is embedded the assumption that a woman's traditional role is in the domestic sphere rather than in production. Mies (1982: 54) found the same happening to Indian women of Narsapur in Andhra Pradesh involved in the cottage industry of lace making. The low status of women was

\footnotetext{
${ }^{7}$ In other contexts of externally driven development in Malaysia, such as commercial logging in remote areas, men brought in as logging workers and the influx of other strangers to the area can endanger local rural communities, especially the safety of women and girls. For instance, in Sarawak, investigations confirmed cases of sexual abuse of Eastern Penan girls and women by the employees of logging companies, with several of the rape victims being schoolgirls as young as 10 years old. This is another dimension of the marginalisation of women and girls within the wider context of marginalised indigenous communities such as the Eastern Penans. For the investigation report, see The Penan Support Group, the Asian Forum for Human Rights and Development (FORUM-ASIA), and the Asian Indigenous Women's Network (AIWN). 2010. A Wider Context of Sexual Exploitation of Penan Women and Girls in Middle and Ulu Baram, Sarawak, Malaysia, SUARAM Komunikasi, Selangor. The investigation report is available at: https://hornbillunleashed.files.wordpress.com/2010/07/penan-report_web.pdf.

${ }^{8}$ Colok are bamboo sticks cut into 10 or 11 inches length, which are then split into slivers for the joss-stick and candlestick industry. At the time of fieldwork (2003), women colok-makers said they spent on average 3-4 hours daily producing colok and earned RM4 for every bundle of 1,000 sticks of 10 inches length or RM4.20 for an 11-inch bundle. Today it is RM5. When I revisited these villages in March 2018, I was informed that many women and men are still active colok-makers.
} 
reflected in the lack of recognition of women's contribution to activities such as cooking, childcare, washing clothes, cleaning and other chores that sustain households from day to day.

\subsubsection{Changes in Livelihoods and Effects on Customs, Traditions and Health}

The multiplicity of meanings and functions centred around natural resources and adat practices were and are of great significance to indigenous women's roles in social and cultural life. Adat has been practised for generations and is rooted in customary land rights. It is not something that can be transplanted into new resettlement areas like transplanting crops (Yong and Wee

2015). Resettlement degrades, uproots and marginalises indigenous women from their traditional authority and roles as custodians, resource managers and transmitters of traditional knowledge in food production, agricultural rituals and healing. It is through the connection to land and their ancestors that indigenous peoples have survived for generations, as a 61-year old Kadazandusun man explained:

I had collected the bones of my buried kin into large Chinese jars and kept them outside my house at the new settlement site. The bones were, and still are, important to me, because I am the seventh descendent of the Tulu Ragang (original descendants) and I want to keep our legacy.

Customary lands were also specific domains of indigenous women and central to their worldview, indigenous identity and culture. Women gathered food and medicines from the forest using their hands-on knowledge of the nutritional and medicinal properties of these plants, roots and leaves. Sabah's Kadazandusun women bobolian/babalian (priestess) were custodians of adat rituals on healing and medicinal plants. The Iban Dayak and Orang Ulu women in Sarawak were caretakers in protecting the paddy spirit (padi pun). For indigenous women relocated to resettlement sites where large commercial oil palm plantations now surround them, their adat rituals and healing practices stopped, since there are no forest resources within the resettlement sites, or they have to travel far to collect forest products (Yong 1994, 1995, 1995a, 2000, 2003). The Iban Dayak displaced by the Batang Ai Dam, for example, were resettled to new places such as Bukit Peninjau adjacent to palm oil plantations. Industrial monoculture tree plantations such as oil palm and eucalyptus plantations that the Food and Agriculture Organisation (FAO) claims are 'planted forests' are viewed by indigenous communities, and many other rural communities elsewhere, as very low biodiversity forests (http://www.wrm.org.uy). Changes resulting from resettlement thus accentuate or exacerbate the destruction of traditional beliefs and practices, reshaping indigenous way of life, gender and social identities.

Food scarcity took a toll on resettled people. In Air Banun I noticed a decline in the traditional practise of food exchange and sharing among the resettled Jahai. Depletion of forest resources and the impoundment of the Temenggor Lake had squeezed household livelihoods, and this had a devastating effect on the Jahai's unique social and cultural way of life.

With the forests gone after resettlement, opportunities for children to explore and learn about the riches of the environment were also gone. Consequently, the younger generation lost the relationship with their land and forests. Children's spaces for playing were now restricted to the football field, if available, and along road pavements and the dam site, endangering children's safety. Due to the nearness of villages like Tampasak and Peretak to the main road, many children were exposed to various influences, especially the "modern" urban lifestyle. This life- 
style they embraced and imitated vigorously, further leading to disinterest in learning and preserving their indigenous culture and knowledge.

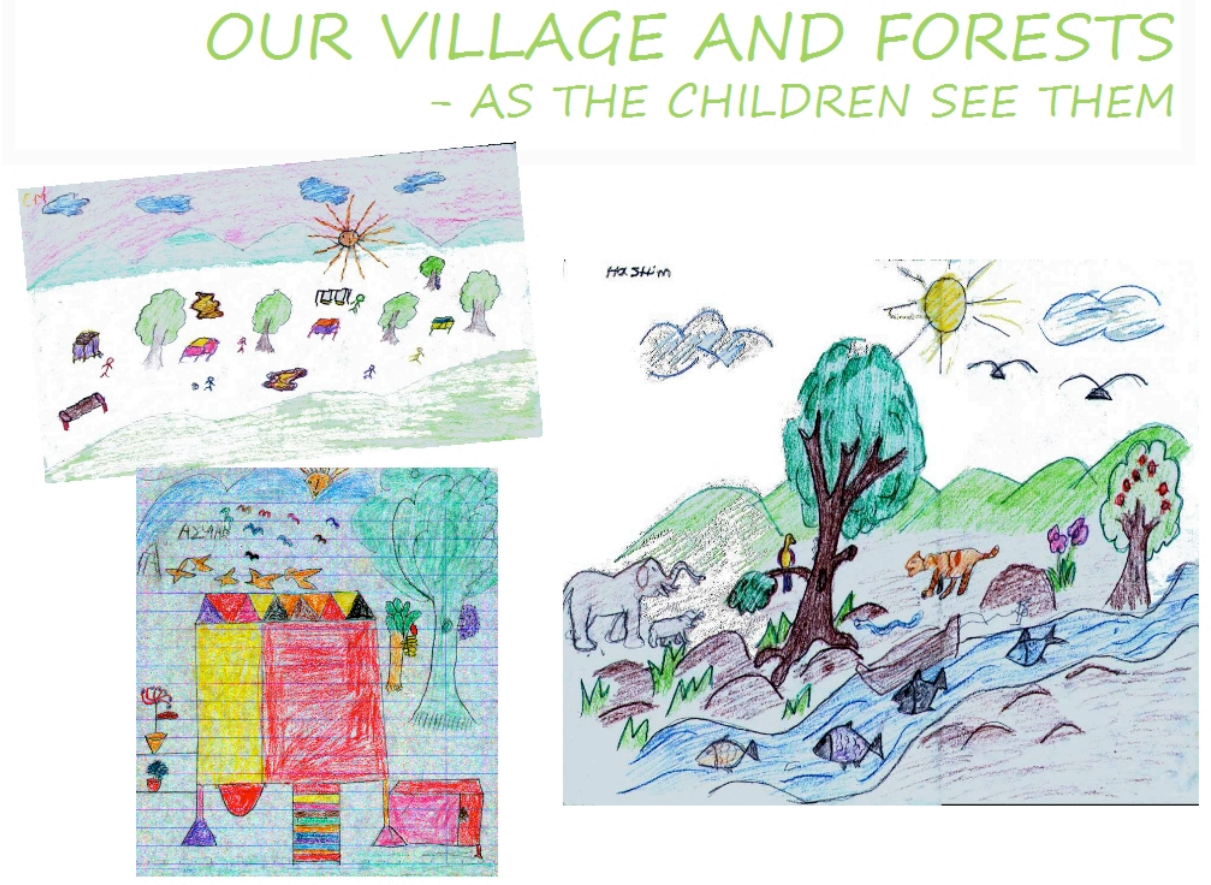

Fig. 6.

Resettlement has adversely affected children and their needs.

(Photo: C. Yong, based on indigenous children's drawings at resettlement sites)

Food insecurity, water, sanitation and other health issues are also crucially linked to degraded environments, and diminished or depleted resources, which affect anyone. However, displaced people are often more at risk of human health impacts (Tilt, Braun and He 2009). Displaced indigenous elders, women, children and persons with disabilities were most affected by the consequences of waterborne diseases (esp. schistosomiasis, a disease transmitted by snails living in slow-moving waters of dammed rivers and lake-streams), poor sanitation and hygiene, as well as lack of quality basic amenities at new settlements. Several studies of Semai children in the Betau Regroupment Scheme found a high prevalence of underweight and stunted children, a high percentage of women and children malnourished or undernourished, and a high prevalence of chronic illnesses (cf. Khor 1994). Food insecurity and undernourishment, according to Cernea (2000), are major impoverishment risks in displacement, but the analysis is flawed, I argue, if it fails to see that these are also gendered aspects.

\subsubsection{Impact of a Changing Livelihood Base on Family and Community Life and Gender Inequalities}

Traditionally, indigenous women, men and children had different gender roles. For instance, hunting involved the whole family, and they went into the forest as a family. Women often collected food and medicines while men hunted. However, the gender division of labour was not pronounced, meaning women also hunted, though for smaller animals, and men also collected forests produce. Children followed their parents to the forest mainly to enjoy exploring the river and forest.

Today, hunting is the men's domain. After resettlement, forests that the men go to for hunting, in groups on motorbikes or in cars, are further away. It is not easy for women and children to go on foot. Sometimes a headman's wife or other female relatives join the hunting, or rattan- 
harvesting trips, if their husbands give permission. This has specific impacts on women, undermining their position and their power to exercise control over their lives, which in turn relegates women to subordinated positions in the family and community. Gender and social inequalities are exacerbated when the power in decision-making and access to resources is in the hands of a few privileged men, limiting the women, children, and poor men. Spheres of decision-making of women and men, as well as individual and collective agency are important issues of gender and land rights in relation to women's negotiation power within the household (Agarwal 1994; Jackson 2003; Razavi 2003; Wanyeki 2003).

Family cohesion and social support networks have changed due to the strain that resettlement placed on families. As previously mentioned, there is increasing pressure on men to find money as loss of land and forests has escalated hardships and eroded livelihoods after resettlement. Men are expected to respond to the notion that men helm the household so they are the main "breadwinner". Some men have found this responsibility difficult to fulfil and have turned to alcohol, alcohol-related violence and gambling, or have overspent on consumer and "modern" lifestyle goods, while others have left their families. Some villagers admitted that drinking had become more serious a year after their resettlement. Women experienced the effects of this social problem differently than men. Some women from Gerachi and Peretak villages said: ${ }^{9}$

Today, men are hitting their wives, something that rarely happened with the Orang Asli.

When the men have some money, they go to the liquor shop and return home drunk, and then they start to quarrel with or hit their wives. Previously women and men foraged and hunted for food together, so they had less time and money to go drinking.

Thukral (1996) identified similar "social disturbances" among the communities in Kohadiya displaced by the Hirakud and Kutku dams in Bihar: alcoholism, prostitution, gambling and theft. Although alcoholism is not necessarily a direct consequence of displacement, forced uprooting increases the risk that people face cultural, economic and power shocks in the new environment after relocation, and they express this shock in various ways (Thukral 1992; Cernea 2000; Mahapatra 1999). Others call it "routine" and "dissonant culture", where forced displacement "destabilises" one's routine culture resulting in "dissonant culture" marked by a "temporary reordering of space, time, relationships, norms and psycho-social-cultural constructs" (Downing and DowningGarci 2009, 2017). I too noted similar "expressions of shock" and "temporal dissonances" in different post-resettlement sites studied over the years.

Informal networks help to strengthen women's bargaining power within the family because of a collective voice. But the new environment is very stressful as households do not have space or privacy, and mutual cooperation in the community was declining as families did not always have time or sufficient resources to share. Changes in family and community structures and practices further marginalised and disempowered women. My findings reported older women, single mothers and women with children as the most disadvantaged groups.

Changes are also evident in indigenous leadership and governing structures in the community. Previously, traditional village institutions led by both female and male elders oversaw the customary land tenure system to ensure fair access and usage of customary land for all community members - men, women and children, as long as they lived with or maintained relations with the family, community or kin group and took collective responsibility for the use of the land. Today,

\footnotetext{
${ }^{9}$ Interview in Kampong Peretak on 10 December 2002.
} 
decision-making is almost entirely controlled by local male leaders appointed by the state and accorded a higher status in the village, and this in turn accords them more privileged power over women and poorer men. Adat still exists but is not applied or followed anymore: for example, elderly women and men have lost their rights to decision-making and giving advice within the household and in the community.

A changing livelihood base of women in particular, and changing gender roles favourable to village heads and local leaders, mostly men, aggravate existing gender and power inequalities at the intra- and inter-households levels. Women experience insecurity of customary rights to land and multiple uses of resources, as they only have secondary rights to land. Women are ignored and under-represented in public decision-making structures, as male village leaders tend to dominate decision-making processes and have a stronger voice in the village. Poorer men are losers too as local decision making over land that was previously part of collectives is now limited to a small group of government-appointed local community leaders, local authorities, state agencies and ruling state and federal representatives.

\section{Gender Analysis of Compensation, Resettlement and Rehabilitation Processes and Policies}

The popular view shared by both the federal and state governments is that monetary compensation for those whose land has been acquired for the dam, plus promises of permanent jobs, free housing with small plots of land, water and electricity supply, infrastructure and better health and educational facilities is enough - a typical standard resettlement package in Malaysia.

Cernea (2008:89) argues that "compensation alone cannot prevent the impoverishment of resettlers and cannot in itself restore and improve their livelihoods." Compensation has also been criticised by various scholars to be poorly conceived and implemented, citing lack of compensation or inadequate compensation, and even human rights abuses (cf. Colchester 1999; Fernandes and Thukral 1989; McDowell 1996; Picciotto et al 2001). Cernea (2008: 92) criticises this as "financing the certainty of repeated failure [his emphasis] and further impoverishment."

I agree, and argue likewise, that many of the problems in post-resettlement contexts of the displaced communities were compounded in the compensation, resettlement and rehabilitation processes at policy and institutional levels. And many of the consequences are gendered. Issues of decision-making on the eligibility criteria of compensation, treatment of the displaced, and the rehabilitation process and packages adopted differ from state to state, and also based on considerations like geographical location of the project, the project date, and various kinds of social groupings. Compensation and resettlement packages do not always benefit communities, and especially not women, due to pervasive gender bias in policies and project design and implementation. Generally, all my case studies show that there is a lack of gender awareness in compensation, resettlement and rehabilitation policies and programmes.

\subsection{Compensation and Rehabilitation: Promises and Realities/Failures}

State actors and dam builders often stress the fact that resettlement packages brought improvements to the lives of displaced communities as they were given their due share of compensation for their "sacrifice for development". My research findings, however, show that many affected 
families were unhappy with the resettlement outcome and compensation payments. There were also differing responses from women and men within the family and in the community. With the exception of the women and kin related to higher-status men in the village, poorer women and men, adult unmarried women and dependents (young and elderly) were most affected by the loss of livelihoods through submergence and the denial of meaningful resettlement or rehabilitation, or what D'Souza (2008) describes, "doubly dispossessed" and becoming even more disempowered economically and marginalised.

Examples abound of resettlement and compensation promises unfulfilled or inadequate. The Kg. Tampasak Kadazandusuns were promised prior to their resettlement that 200 acres with grazing land would be provided to them. But when they were resettled they were only granted 50 acres of land at the new settlement site to make up for the loss of land and resources. Another example is the Batang Ai Resettlement Scheme in Sarawak where the native Iban were promised free longhouses, free electricity, free water supply, sufficient land for cultivation and cash compensation by the Sarawak state government if they made way for the dam. Their experience, however, was mainly one of "broken promises, dislocation and maladjustment" (Hew and Kedit 1987; Ng 1990; Tan 1997). When I revisited the Temuan in Kg. Gerachi and Kg. Peretak in March 2018, two women told me they and other families had not yet been given the plot of land (2.4 ha and 0.4 ha, respectively) promised to them. An elderly man stated that the land had not been issued with a title yet for registration under the individual owner's name.

Actual payments made to displaced people are generally lower than the amount promised before the resettlement, and if compensation is paid at all, it is often insufficient to purchase new land (McCully 1996: 65-100). Citing cases such as the Itaipu and Tucurui dams resettlement in Brazil and the Kulekhani dam resettlement in Nepal, McCully argues that many indigenous and tribal farmers were not compensated because they had only customary but not formal legal title to the land. Additionally, at the Tucurui reservoir, it was reported that only $20.8 \%$ of the 4,334 properties surveyed had property titles, while in the Sobradinho resettlement (Brazil) two thirds of the farmers were apparently denied compensation entitlements because they lacked titled ownership.

The compensation package for the Orang Asli displaced by the Temenggor Dam in the 1970s was much worse comparatively. The Orang Asli were located in a more remote and security-curfew area (Gerik) and undoubtedly not enough publicity and stronger opposition to their resettlement was raised (Yong 2006). Many of the families in Air Banun never received the new houses, electricity, piped water and a range of development projects promised to them (Jimin 1978). Another study found that only 15 houses had been built for the 266 Orang Asli families and the two agricultural projects, the orchard and rubber planting projects, aimed at restoring their livelihoods, also failed (Itam Wali 1993: 46). Although the Orang Asli there were given "special passes" to enter the Temenggor Lake site for fishing and to enter the nearby jungle to gather jungle produce - since it is restricted area due to the communist insurgency - the living conditions of the families worsened.

Guha's (2013) micro-level study of land dispossession in West Bengal carried out during the period of communist government that coincided with a more general liberalisation found that land acquisition by big industrial projects has caused landlessness and household-level food insecurity among poor farmers. Not even compensation money could help them rebuild their household economies. Another study on Indonesia reported that displaced families who were 
provided only cash compensation had suffered about a 50\% reduction in income compared to pre-project conditions, and their productive resource base was reduced by $47 \%$ (Partridge 1989, cited in Cultural Survival 1994). A study on the Philippines of those resettled in the 1950s to make way for the Ambuklao and Binga Dams found that they were still waiting to be compensated for their losses (Women Workers' Programme 1996, cited in Cochester 1999: 23).

Elsewhere, in Turkey, at the Atatürk Dam and other dam sites being developed, such as the Ilisu Dam as part of the greater Anatolia Project, the vast majority of people displaced, many of them Kurds, were not compensated or rehabilitated at all and left to fend for themselves (KHRP 2003, 2005). In south-central Brazil in 1979, among the 6,200 people displaced, including the Afaye-Xavante Indians, by the Porto Primavera hydroelectric dam, it was only the landowners through their private attorneys who received "just" compensation, while the farm workers, fishers, peasants and Indians were simply dumped elsewhere (http://pluginhead.i-us.com/ porto/environ.htm, accessed 20/10/2000).

Considerable discontent has arisen over a number of issues: the differential compensation paid to different individuals and families, underestimated cultural, social and economic values which resulted in under-compensation, biases in the distribution of the compensation money, and the gap between promised and delivered compensation. At all the research sites, suspicion and jealousy over who got how much has led to inter-family relations breaking up, and conflicts between husbands and wives, parents and children and amongst children. The Adivasi communities in the state of Orissa in eastern India displaced by the Hirakud Dam are one such example. According to D'Souza (2008: 13), the bureaucratic and formal categories of "atomized individuals", breaking up whole communities into oversimplified family units, to address compensation claims in the implementation of resettlement and rehabilitation programmes, "have led to the forced snapping of deep historical ties, bonds, and cultural linkages that were critical to survival strategies and livelihood means", especially of Adivasis that previously existed as culturally dense intertwined units.

Most importantly, the compensation costs omitted non-quantifiable and non-monetary values on which indigenous peoples' livelihoods, identity and culture were based. Customary lands compulsorily acquired for dams were not entitled to compensation, including the resources and crops planted on them, because they were without legal status (official titles or deeds). Accordingly, state and dam proponents could circumvent the rules and refused to accept the multiple levels of sovereignty over the resources on which the dam had encroached. As Hirsch (1996: 221) argues,

Resource values destroyed by dams are very difficult to replace in standard compensation and resettlement procedures, given the limited role of affected people in planning and the reductionism that simplifies complex aspects of culture, settlement, local history and relations between people and their resource base into a monetary figure or a settlement program designed by external consultants.

\subsection{Gendered Consequences}

Poorly conceived and implemented compensation and rehabilitation packages have many farreaching consequences. Assessments and plans should start with considering the mixed and varied needs of women, men, and children, or other vulnerable groups within the communities, 
but they do not in practice. Instead, women and men are seen as a homogenous group. It is certainly not the case that either all women or all men are negatively/positively affected by resettlement experiences, however, most rehabilitation activities for the restoration of peoples' livelihoods and adaptation to changes promote "repeated failures" (cf. Cernea 2008) because they overlook differences in gender, age, and socio-economic and political status.

Compensation also changes the configuration of intrahousehold power, and that can alter preexisting gender and social relationships and structures in various ways. For instance, compensation is given to men as the assumed heads of household, and women and children considered as their dependents. This assumption is the root cause behind the discriminating of de facto female household heads, unmarried single mothers, and women who are divorced, deserted or widowed (bachelors and widowers are also disproportionately affected). Dependents are normally not eligible to get compensation from the state with a few exceptions. Similarly, compensation in kind, e.g. employment at dam sites, inadvertently favours men over women, especially since work in these projects is assumed to be heavy and unsuitable for "the weaker sex".

Gender stereotyping is also found in community development programmes as part of rehabilitation and livelihood restoration programmes for the Orang Asli, specifically the Taklimat Rumah Sempurna (familiarisation programme). Before relocating the Temuan to $\mathrm{Kg}$. Gerachi and $\mathrm{Kg}$. Peretak, the men were provided training and jobs in construction, while women were taught how to handle and use modern house equipment and appliances, household management, cleanliness and hygiene. This gender stereotyping of women to be "good wives and mothers" and men as breadwinners reveals the gender bias in an approach that does not take into account women in the mainstream labour force and men rendered jobless and only relying on compensation money.

I have also encountered the view that men receiving the compensation money means equal sharing in the family and everyone equally reaps the benefits. Behind this assumption is the thinking that men are supposed to represent women's thinking as well. Denying women their power and rights to control household finances further increases their dependence on men.

The position of both women and poorer groups are disproportionately affected by cash compensation. There is a big gap between compensation received by ordinary households and village heads and community leaders, the latter gaining the most. In one village, several people murmured about "the batin (head of the village) who had received a big compensation" and showing off his wealth in owning a few motorcycles, cars, a 4-wheel drive and many modern electrical appliances. This headman was apparently well connected to the state and local authorities and dam authorities, which helped to reinforce his power and influence beyond the village boundary. Compared to the other villagers he was wealthy. Since women's position is dependent on the social standing of the men, the position of his wife and daughters ranked above the other women in the village. This had divided the community into the powerful haves and the weak have-nots.

Numerous studies have highlighted the negative effects of sudden cash inflow on indigenous peoples and tribal minorities, using up their compensation quickly in gambling, drinking, and modern consumption (e.g. Thukral 1992; Viegas 1996). For example, Viegas highlights the problem of liquor available in abundance among the Hirakud Dam oustees in Orissa. When the compensation money ran out, it increased the pressure on families and individuals, introducing inequality and undermining social cohesion, and pushing some women into prostitution. In Laos, the provincial office of the Attapeu Lao Women's Union reported that 15 Lao Theung 
women displaced by the Houay Ho Dam had become prostitutes for workers on the construction site, the first time prostitution had been recorded in the area, raising the possibility of AIDS being introduced in a region with very poor public health services (Colchester 1999: 25).

\section{Conclusions}

Mines, dams, plantation schemes, cattle ranches, highways and other "development" projects have seized indigenous peoples' ancestral lands with little or no compensation, and even where new land is given it is rarely adequate or fertile enough to sustain livelihoods (Brody 2002; Carino 1999; Colchester 1999; Howitt, ed. 1996; McCully 1996; WCD 2000; WRM 2003). Compensation and resettlement packages often fail to take gender and gender issues into consideration. Women are marginalised and invisible in the design and implementation of compensation, resettlement and rehabilitation policies and programmes that give lesser priority to women (Yong 2017). Why is a gender analysis of compensation, resettlement and rehabilitation processes and policies important in dams displacement and resettlement? This is an essential first step to challenge the assumption that the benefits of development are shared equitably, irrespective of gender, class, ethnicity, and caste (cf. Sen and Grown 1987; Heyzer and Sen 1994; Ng 1999). The related question in my case studies, "how did the Malaysian state/federal government consult with and obtain 'consent' from the indigenous communities to give up their lands for the dam?", further helps in understanding how these 'development' projects are simply implemented, rather than exploring alternatives to dams.

\subsection{Laying the Ground Work: Women on the Periphery}

Laying the ground work has to start with understanding how the different social groups in the affected communities - men and women (gender), old people and young people (generational), and village/community leaders and ordinary villagers (status) - can make meaningful decisions concerning their future. If there is consensus, appropriate institutional frameworks need to ensure that decision-making benefits everyone. In practice, in Malaysia, the state created a standard procedure (framework) that has yet to legislate guarantees for the recognition of indigenous peoples' rights to their customary lands, traditional territories and resources, and in accordance with fundamental principles enshrined in international laws, human rights laws, and international/UN conventions and declarations for projects that affect indigenous peoples. The affected peoples' rights to information, consultation, representation, effective participation, and free, prior, and informed consent has so far hardly been applied..$^{10}$ This, however, has to take place at the earliest phase of the planning process, before any activity related to the proposed project commences.

\footnotetext{
${ }^{10}$ In the wider context, this includes public consultation with residents indirectly affected such as downstream communities, and residents that are supposed to benefit from the dam. This aspect is not covered in this paper.
} 


\subsection{Village Leadership: Male-Oriented}

On the whole, the authorities and the dam developers/contractors relied on the formal village structures, i.e. the village-head and the Jawatankuasa Keselamatan dan Kemajuan Kampong (JKKK) or Village Security and Development Committee, and selected individuals to be the points of contact between them and the community. This is where the fundamental problem lies - in the wider political context. The village-head and committees are government-appointees and they are mostly men. This is not the way traditional decision-making structures work. Village leaders in the traditional context follow adat, which works for the welfare of the community in egalitarian ways. The position of women and girls, especially those at most risk, is considered.

Indigenous communities have complex ways of working that are not adapted to outside interference. Yet, the JKKK members started to interact with the communities and endorsed decisions pre-determined by the state and dam developers, while the village head and other village leaders, predominantly male, represented their communities in negotiations with the state agencies and dam developers. If the formal structures had a gender bias, this led to the fact that gender-related questions were not properly addressed.

\subsection{Access to Information}

In almost all the dam projects in Malaysia, the affected people were kept in the dark about the project plans until bulldozers, dump trucks, and construction crews moving equipment onto their land became visible. Dam projects tend to be very secretive, regarding, for example, the dam developers, the technical information, the reports (pre-assessment, EIA, etc), and especially precise numbers: of villages, homes, families, individuals, hectares to be affected partially or entirely, and actual costs/benefits. For the Babagon Dam, when the community-elected representatives, mostly women since they were vocal against the proposed dam, wrote to the state authorities for information, they were informed the Babagon Dam was a "project of public interest" but substantial data was classified as "confidential". This clearly violated the rights of the community to have access to information related to the proposed dam.

At the formal village level, the planners and officials used the village leaders as "legitimate" representatives of the community, channelling any information people should know via them and to give "consent" on behalf of the community. At times village leaders' wives were "consulted" on women's views, but on the whole, women were invisible. Many women, the elderly and the illiterate often remained uninformed - relegating them to a lower status. They received information from the male members of the family, who received it from the male leaders, who controlled the release of the information to different groups within the community. As a result, different persons and families received information that was unclear, ambiguous and contradictory.

The dams and resettlement of indigenous peoples that I have researched cover different geographical locations and differing time periods of dam construction and resettlement of affected people: Temenggor Dam (1972-1975), Babagon Dam (1992-1997) and Sg. Selangor Dam (1999-2003). The different time periods and settings are critical factors determining how the affected individuals and groups were treated by the state and dam developers; the status of the projects (high or low profile); the limited or wider opportunities for the displaced communities 
to exert their agency and power; the availability, or lack thereof, of external allies (media, researchers, NGOs) and the level of publicity, external support, and opposition to the dams being planned.

The contrast of the Temenggor Dam and Sg. Selangor Dam is an apt example of how the peoples affected by the respective projects, about 25 years apart, were treated in terms of compensation and resettlement package:

- The Temenggor Dam was one of the earlier dam-displacement projects in Malaysia, located about $300 \mathrm{~km}$ from the capital city KL and in a remote military security area. Public entry was prohibited until the late 1980s. The resettlement of the Jahai in 1979 was little known. Public involvement and the Orang Asli resistance against the dam was relatively unheard of.

- The Sg. Selangor Dam resettlement of the Temuan in 2001 was located about $60 \mathrm{~km}$ from KL, accessible by land vehicles. The presence of a group of local villagers openly resisting the dam, led by a high-profile Asli singer, established links with a group of outside urban musicians. There was growing national and international recognition of dams and impacts on indigenous peoples as a result of international human rights law and conventions, WCD and dams resistance worldwide.

Is there a way forward to protect the rights of the indigenous peoples in Malaysia from dams and forced displacement and resettlement? Malaysia does not have a national resettlement and compensation policy for dealing with development projects involving the acquisition of land. Thus far, the whole process of compensation, resettlement and rehabilitation has been largely decided by the state along with the dam contractors, which remains ad hoc and piecemeal. Besides, a comprehensive and transparent approach to dealing with the issue of displacement is not yet in place.

Putting legislation in place is definitely not the only solution to problems faced by the indigenous communities displaced by dams such as the Babagon, Temenggor and $\mathrm{Sg}$. Selangor dams. But considering that indigenous peoples and especially women continue to disproportionately suffer from the negative impacts of development policies and projects, legislation could at least ensure that resettlement plans and their implementation abide by certain principles, using the WCD framework as a starting point, for example (WCD 2000: 213-259).

Another factor is the availability of international conventions, policies and legal instruments that have included guidelines on involuntary resettlement, gender, and so forth. The United Nations Declaration on the Rights of Indigenous Peoples (UNDRIP 2007), the Convention on the Elimination of All Forms of Discrimination against Women (CEDAW), the Beijing Platform for Action, the UN's 2030 Sustainable Development Goals (SDGs), the Asian Development Bank's Gender Checklist: Resettlement (2003), the World Bank Gender and Development Policy Framework - A Guidance Note (2010), and the Government of Australia's policy paper on "Displacement and Resettlement of People in Development Activities" (July 2015), are a few among these.

Based on the many issues and lived experiences of the resettled indigenous peoples and communities due to the construction of dams in Malaysia that I have presented above, I believe there is an urgent need to acknowledge the gender and land rights issues affecting indigenous peoples and communities, where indigenous women are doubly disadvantaged in displacement 
by dam projects. The standards, principles and obligations under international laws and international human rights for projects that affect indigenous peoples can provide guidance and pressure on the state in dam building.

Carol Yong holds a PhD in Development Studies from the University of Sussex (UK) and a Masters in Development Studies from Universiti Malaya (Malaysia). She has done extensive research on development-induced displacement and resettlement affecting Malaysia's indigenous peoples. She conducts continuous research on indigenous peoples in Malaysia and Indonesia, and other marginalised peoples globally, from a gender, environment, human rights and community/indigenous peoples' rights perspective. A Malaysian feminist activist and independent researcher/consultant with many years' experience, she has written and published on diverse issues including gender and development, human rights, land tenure and disasters, resource politics and corruption. She also serves as honorary gender advisor to Indonesian NGOs and community activist groups. 


\section{Literature}

Adams, W.M. 2001. Green Development: Environment and Sustainability in the Third World. Second edition. Routledge, London and New York.

ADB (Asian Development Bank). 2003. Gender Checklist: Resettlement. Accessed at: http://www.adb.org/sites/default/files/pub/2003/gender-checklist-resettlement.pdf

Agarwal, B. 1996. A Field of One's Own. Gender and Land Rights in South Asia. Cambridge: Cambridge University Press.

Bag, Minaketan. 2017. Industrialization: A Critical Analysis of Gender Inequality through the Anthropological Lens. IOSR Journal of Humanities and Social Science (IOSR-JHSS) 22(9): 37-46.

Brody, Hugh. 2002. Maps and Dreams, London: Faber and Faber.

Bryan Tilt, Yvonne Braun, Daming He. 2009. Social Impacts of Large Dam Projects: A Comparison of International Case Studies and Implications for Best Practice. Journal of Environmental Management 90: 249-257.

Carino, Joji. 1999. The World Commission on Dams: A Review of Hydroelectric Projects and the Impact on Indigenous Peoples and Ethnic Minorities. Cultural Survival Quarterly 23(3).

Cernea, M. M. 2008. Compensation and Benefit Sharing: Why Resettlement Policies and Practices Must be Reformed. Water Science and Engineering 1(1): 89-120.

Cernea, M. M. and S. E. Guggenheim (eds.). 1993. Anthropological Approaches to Resettlement: Policy, Practice and Theory. Boulder: Westview Press.

Cernea, M. M. and C. McDowell (eds.). Risks and Reconstruction: Experiences of Resettlers and Refugees. Washington DC: World Bank, 1-50.

Colchester, M. 1999. Sharing Power: Dams, Indigenous Peoples and Ethnic Minorities. Indigenous Affairs, vol. 3-4. Copenhagen: International Work Group for Indigenous Affairs, 4-54.

Colson, Elizabeth. 1971. Social Consequences of Resettlement. Manchester: Manchester University Press.

- 1999. Engendering Those Uprooted by 'Development', in: Indra D. (ed.), Engendering Forced Migration: Theory and Practice. Oxford: Refugee Studies Program, 23-39.

- 2003. Forced Migration and the Anthropological Response. Journal of Refugee Studies 16(1): 117.

Cliggert, Lisa. 2010. Aging, Agency, and Gwembe Tonga Getting By. Journal of Aging, Humanities, and the Arts 4(2): 98-109.

Cliggert, Lisa. 2001. Survival Strategies of the Elderly in Gwembe Valley, Zambia: Gender, Residence and Kin Networks. Journal of Cross-Cultural Gerontology 16(4): 309-332.

Downing, Theodore E. and Carmen Garcia-Downing. 2009. Routine and Dissonant Culture: A Theory about the Psycho-Socio-Cultural Disruptions of Involuntary Displacement and Ways to Mitigate them Without Inflicting Even More Damage, in: Oliver-Smith, Anthony (ed.), In Development and Dispossession: The Anthropology of Displacement and Resettlement. Santa Fe: School for Advanced Research Press, 225-254.

- 2017. Re-negotiating Gendered Space and Time when People are Forcibly Displaced: Strategic Planning and Tactical Execution. Paper prepared for the International Conference on Gender and Displacement: Evidence and Policy Implications, co-organised by the World Bank, UNWOMEN and the Ministry of Labour, Invalids and Social Affairs (MOLISA), Vietnam. April 13-14, 2017. Ha Long, Vietnam. Unpublished paper.

Fernandes, W. (Undated). Displacement, Internal Refugees, Common Property Resources and Women. 
Fernandes, W., and E. G. Thukral (eds.). 1989. Development, Displacement and Rehabilitation: Issues for National Debate. New Delhi: Indian Social Institute.

Gadgil, Madhav and Guha, Ramachandra. 1994. Ecological Conflicts and the Environmental Movement in India. Development and Change 25(1): 101-136.

Ghai, Dharam. 1994. Environment, Livelihood and Empowerment. Development and Change 25: 111.

Goldsmith, Edward and N. Hildyard (eds.). 1984. The Social and Environmental Effects of Large Dams, Vol. I: Overview, A Report to the European Ecological Action Group (ECOROPA); Vol. II: A Report to the European Ecological Action Group (ECOROPA). Cornwall: Wadebridge Ecological Centre.

Griffen, Vanessa (ed.). 2001. Seeing the Forest for the People: A Handbook on Gender, Forestry and Rural Livelihoods. Kuala Lumpur: Gender and Development Programme (GAD), Asian and Pacific Development Centre (APDC).

Guha, Abhijit. 2013. The Macro-Costs of Forced Displacement of the Farmers in India: A MicroLevel Study. European Journal of Development Research 25(5): 797-814.

Hew, Cheng Sim and Flora Kedit. 1987. The Batang Ai Dam Resettlement and Rural Iban Women, in: Noeleen Heyzer (ed.), Women Farmers and Rural Change in Asia. Kuala Lumpur: Asian and Pacific Development Centre.

Heyzer, Noeleen and Gita Sen (eds.). 1994. Gender, Economic Growth and Poverty: Market Growth and State Planning in Asia and the Pacific. New Delhi, Utrecht and Kuala Lumpur: Kali for Women. International Books and Asian and Pacific Development Centre.

Hilhorst T. 2000. Women's Land Rights: Current Developments in Sub-Saharan Africa, in: Toulmin C. \& Quan J (eds.), Evolving Land Rights, Policy and Tenure in Africa. DFID/IIED/NRI, 182.

Him Dhara. 2011. Environment Research and Action Collective. In the Name of Clean Energy. A Report on Asian Development Bank Financed Hydropower Projects in Himachal Pradesh.

Hirsch, Philip. 1996. Dams and Compensation in Indo-China, in: Howitt, Richard, J. Connell and P. Hirsch (eds.), Resources, Nations and Indigenous Peoples: Case Studies from Australasia, Melanesia and Southeast Asia. Melbourne: Oxford University Press, 212-22.

Howitt, Richard, John Connell and Philip Hirsch (eds.). 1996. Resources, Nations and Indigenous Peoples: Case Studies from Australasia, Melanesia and Southeast Asia. Melbourne: Oxford University Press.

HRC (Human Rights Clinic). 2010. Swimming against the Current: The Teribe Peoples and the El Diquis Hydroelectric Project in Costa Rica. The University of Texas School of Law.

Ideal Times. 1999. Tanah Pengidup Kita - Our Land is Our Livelihood: The Undermining of Indigenous Land Rights and the Victimisation of Indigenous People in Sarawak. Sibu: Ideal Time Sdn. Bhd.

Indra, Doreen (ed.). 1999. Engendering Forced Migration: Theory and Practice. Refugee and Forced Migration Studies, vol. 5. New York and Oxford: Berghahn Books.

INSAN. 1996. Power Play: Why the Bakun Hydroelectric Project is Damned. Kuala Lumpur: Institute of Social Analysis (INSAN).

IRN. 2005. $5^{\text {th }}$ Anniversary of the WCD Report, WCD+5. Conference Report: Taking the WCD Report to the Next Level. Berlin, November 15.

Itam Wali bin Nawan. 1993. Rancangan Pengumpulan Semula (RPS) Orang Jahai: Kajian Kes Mengenai Perubahan Sosial di RPS Air Banun, Jabatan Anthropologi dan Sosiologi, Universiti Kebangsaan Malaysia, Bangi. [The Jahai: A Case Study of Social Change in the Air Banun Re- 
groupment Scheme. Anthropology and Sociology Department, National University of Malaysia, Bangi].

Jackson, Cecil. 2003. Gender Analysis of Land: Beyond Land Rights for Women? Journal of Agrarian Change 3-4: 453-480.

Jimin, Idris. 1978. The Regroupment of the Orang Asli within the Titiwangsa Region of Peninsular Malaysia. M.Phil thesis, St. John's College, University of Cambridge.

Jimin Idris, Mohd Tap Salleh, Jailani M. Dom, Abd. Halim Haji Jawi and Md. Razim Shafie. 1983. Planning and Administration of Development Programmes for Tribal Peoples (The Malaysian Setting). Kuala Lumpur: Center for Integrated Rural Development for Asia and the Pacific.

Kabeer, Naila. 1994. Reversed Realities: Gender Hierarchies in Development Thought. London and New York: Verso.

Khor, Geok Lin. 1994 Resettlement and Nutritional Implications: The Case of Orang Asli in Regroupment Schemes, Pertanika: Journal of the Society for Science and Humanity 2(2): 123-132.

Kothari, Smitu. 1996. Whose Nation? The Displaced as Victims of Development. Economic and Political Weekly 31(24): 1476-1485.

KHRP. 2003. 'This is the Only Valley Where We Live': The Impact of the Munzur Dams. Report of the KHRP Fact-Finding Mission to Dersim/Tunceli. London: Kurdish Human Rights Project.

KHRP. 2005. The Cultural and Environmental Impact of Large Dams in Southeast Turkey. FactFinding Mission Report. Written by Maggie Ronayne, National University of Ireland, Galway and Kurdish Human Rights Project, London.

Koenig, Dolores. 1995. Women and Resettlement, in: Gallin, Rita S., A. Ferguson, and J. Harper (eds.), The Women and International Development Annual 4: 21-49.

- 2002. Towards Local Development and Mitigating Impoverishment in Development-Induced Displacement and Resettlement. Final Report (abridged). Prepared for ESCOR R7644 and the Research Programme on Development-Induced Displacement and Resettlement organised by the Refugee Studies Centre, University of Oxford. July 2001/January 2002.

Kusakabe, Kyoko. 2017. Why Resettlement and Gender? Paper presented to the International Conference on Gender and Displacement: Evidence and Policy Implications, co-organised by the World Bank, UNWOMEN and the Ministry of Labour, Invalids and Social Affairs (MOLISA), Vietnam. April 13-14, 2017. Ha Long, Vietnam. Unpublished paper.

Lim Hin Fui. 1997. Orang Asli, Forest and Development. Malayan Forest Records 43. Kepong: Forest Research Institute Malaysia.

Mahapatra, L. K. 1999. Testing the Risks and Reconstruction Model on India's Resettlement Experiences, in: Cernea, M. (ed.), The Economics of Involuntary Resettlement: Questions and Challenges. Washington DC: World Bank, 189-230.

Malaysiakini. 2018, October 31. Sabah cabinet approved Papar Dam Project, Says Shafie. https://www.malaysiakini.com/news/449747. Accessed 2 November 2018.

McCully, Patrick. 1996. Silenced Rivers: The Ecology and Politics of Large Dams. London: Zed Books.

McDowell, Christopher (ed.). 1996. Understanding Impoverishment: The Consequences of Development-Induced Displacement. New York: Berghahn Books.

Mies, Maria. 1982. Lace Makers of Narsapur: Indian Housewives Produce for the World Market. London: Zed Books.

Moore, Henrietta L. 1988. Feminism and Anthropology. Cambridge: Polity Press. 
Morse, B. and Berger, T. 1992. Sardar Sarovar: The Report of the Independent Review. Ottawa, Canada: Resource Futures International.

Ng, Cecilia. 1994. The Woman Question: Problems in Feminist Analysis. Kajian Masyarakat 12(12): 190-204.

- 1999. Positioning Women in Malaysia: Gender and Class in an Industrializing State. New York and London: St. Martin's Press and MacMillan Press.

Oliver-Smith, Anthony. 2002. Displacement, Resistance and the Critique of Development: From the Grassroots to the Global. Final Report prepared for ESCOR R7644 and the Research Programme on Development Induced Displacement and Resettlement. Refugee Studies Centre, University of Oxford.

Patridge, William L. 1989. Involuntary Resettlement in Development Projects, Journal of Refugee Studies 2(3): 373-384.

Pattanaik, S.K., B. Das and A.B. Mishra. 1987. Hirakud Dam: Expectations and Realities, in: PRIA (ed.), People and Dams. New Delhi: Society for Participatory Research in Asia, 47-59.

Pearce, Fred. 1992. The Dammed: Rivers, Dams, and the Coming World Water Crisis. London: The Bodley Head.

Picciotto, Robert, Warren van Wicklin, and Edward Rice (eds.). 2001. Involuntary Resettlement: Comparative Perspectives. World Bank Series on Evaluation and Development, Volume 2. New Brunswick and London: Transaction Publishers.

PRO Kew. 1952. File Reference: CO 1022/29. No. 33 of 1952, Resettlement and the Development of New Villages in the Federation of Malaya.

Razavi, S. 2003. Agrarian Change, Gender and Land Rights: Introduction. Journal of Agrarian Change 3(1-2): 2-32.

Sapkota, Nogendra and Ferguson, Scott. 2017. Asian Development Bank: Involuntary Resettlement and Sustainable Development - Conceptual Framework, Reservoir Resettlement Policies, and Experience of the Yudongxia Reservoir. No. 9 July.

Scudder, Thayer. 1993. Development-Induced Relocation and Refugee Studies: 37 Years of Change and Continuity Among Zambia's Gwembe Tonga. Journal of Refugee Studies 6(2): 123-152.

- 2005. The Future of Large Dams: Dealing with the Social, Environmental and Political Costs. London: Earthscan.

Scudder, Thayer and Colson, Elizabeth. 1979. Long-term Research in Gwembe Valley, Zambia, in: Foster, G. M. et al. (eds.), Long-term Field Research in Social Anthropology. New York: Academic Press, 227-54.

Scudder, Thayer and Habarad, Jonathan. 1991. Local Responses to Involuntary Relocation and Development in the Zambian Portion of the Middle Zambezi Valley, in: Mollett, J.A. (ed.), Migrants in Agricultural Development: A Study of Intrarural Migration. Basingstoke and London: Macmillan, 178-205.

Sikka, G. 2014. The Case of Missing Toilets in Sardar Sarovar Dam Resettlements in Vadodara, Gujarat. GeoJournal 81(2): 257-266.

Srinivasan, B. 1997. In Defense of the Future. Mumbai: Vikas Adhyayan Kendra.

SUARAM (Suara Rakyat Malaysia). 1999. Empty Promises, Damned Lives: Evidence from the Bakun Resettlement Scheme in Sarawak. Final Report of the Fact Finding Mission of the Coalition of Concerned NGOs on Bakun, 7-14 May. Petaling Jaya. 
SUHAKAM (Human Rights Commission of Malaysia). 2009. Suhakam's Report on the Murum Hydroelectric Project and its Impact towards the Economic, Social and Cultural Rights of the Affected Indigenous Peoples in Sarawak. Kuala Lumpur.

Tan Pek Leng. 1997. Malaysia, in: Vinod, Raina, Chowdhury, Aditi and Chowdhury, Sumit (eds.), The Dispossessed: Victims of Development in Asia. Hong Kong: ARENA Press, 219-255.

Thambiah, Shanthi. 1995. Culture as Adaptation: Change Among the Bhuket of Sarawak, Sarawak. Unpublished Doctor of Philosophy Thesis, University of Hull.

Thukral, Enakshi Ganguly. 1996. Development, Displacement and Rehabilitation: Locating Gender. Economic and Political Weekly 31(24): 1500-1503.

Thukral, Enakshi Ganguly (ed.). 1992. Big Dams, Displaced People: Rivers of Sorrow, Rivers of Change. New Delhi: Sage Publications.

UNDRIP (United Nations Declaration on the Rights of Indigenous Peoples). 2007.

Van der Sluys, Cornelia, M.I. 1992. The Worldview of the Jahai: Hunter-Gatherers, Traders cum Small-Scale Swidden Cultivators in the Tropical Rainforest of Northern Perak, Malaysia. Preliminary Research Report, Leiden University, Netherlands.

Viegas, Philip. 1992. The Hirakud Dam Oustees: Thirty Years After, in: Thukral, Enakshi Ganguly (ed.), Big Dams, Displaced People: Rivers of Sorrow, Rivers of Change. New Delhi: Sage Publications, 40-42.

Wanyeki, L. Muthoni (ed.). 2003. Women and Land in Africa: Culture, Religion and Realizing Women's Rights. Cape Town: Zed Books.

World Commission on Dams. 2000. Dams and Development. A New Framework for Decisionmaking. The Report of the World Commission on Dams. London and Sterling: Earthscan.

Witness for Peace (WFP). 1996. A People Dammed: The Impact of the World Bank Chixoy Hydroelectric Project in Guatemala. Washington D.C.: WFP.

Whitehead, A. 1984. 'I'm hungry, mum': The Politics of Domestic Budgeting, in: Young, Kate, C. Wolkowitz and R. McCullagh (eds.), Of Marriage and the Market: Women's Subordination Internationally and its Lessons. London: Routledge and Kegan Paul, 93-116.

WRM 2003. Dams: Struggles Against the Modern Dinosaurs. Montevideo: World Rainforest Movement (WRM).

Yong, Ooi Lin Carol. 2017. Invisible Again: Gender Issues in Resettlement with Dams in Malaysia. Paper presented to the International Conference on Gender and Displacement: Evidence and Policy Implications, co-organised by the World Bank, UNWOMEN and Ministry of Labour, Invalids and Social Affairs (MOLISA), Vietnam. April 13-14, 2017. Ha Long, Vietnam. Unpublished paper.

— 2015 (with Wee, Aik Pang). Gender Impact of Large-Scale Deforestation and Oil Palm Plantations Among Indigenous Groups in Sarawak, Malaysia, in: Kusakabe, Kyoko et al. (eds.), Gender and Land Tenure in the Context of Disaster in Asia. Springer Briefs in Environment, Security, Development and Peace 21, 15-31.

- 2015a (with Frans R. Siahaan and Andreas Burghofer). Gender, Land Tenure, and Disasters in the Mentawai Islands, Indonesia, in: Kusakabe, Kyoko et al. (eds.). Gender and Land Tenure in the Context of Disaster in Asia. Springer Briefs in Environment, Security, Development and Peace 21, 89-104.

- 2008. Autonomy Reconstituted: Social and Gender Implications of Resettlement on the Orang Asli of Peninsular Malaysia in Resurrection, in: Bernadette P. and R. Elmhirst (eds.), Gender and 
Natural Resource Management: Livelihoods, Mobility and Interventions. London and Sterling: Earthscan, 109-126.

- 2006. Dam-Based Development in Malaysia: The Temmenggor and Sungai Selangor Dams and the Resettlement of the Orang Asli. Doctoral thesis submitted to the University of Sussex.

- 2006a. Autonomy re-constituted: Social and gendered implications of dam resettlement on the Orang Asli of Peninsular Malaysia. Gender, Technology and Development 10(1): 77-99.

- 2003. Flowed Over: The Babagon Dam and the Resettlement of the Kadazandusun in Sabah. Subang Jaya: Centre for Orang Asli Concerns.

- 2001. Gender Impact of Resettlement: The Case of Babagon Dam in Sabah, Malaysia. Gender, Technology and Development 5(2): 223-244.

- 2000. Gender Perspectives on Land Rights: The Experience of Indigenous Peoples in Malaysia. Paper presented at the Panel on Governance: Gender Perspectives on Land Rights, Intrahousehold Allocations and Productivity. The International Association for Feminist Economics 2000 Conference, 15-17 August, Istanbul. Unpublished paper.

- 1995. For Land, for Life. Issue paper prepared for the All Women's Action Society (AWAM) and presented at the AMAM Workshop on Globalisation and Women's Rights, 5 September, Fourth World Conference on Women/NGO Forum on Women, 30 August - 8 September, Beijing/Huairou, China. Unpublished paper.

- 1995a. Community-Based Agricultural Practices towards Sustainable Land Uses, with Specific Reference to Sarawak's Iban Indigenous Community. Paper presented at the International Seminar on Women in Agriculture and their Participation in the Development and Use of Agricultural Technologies. Organised by the China-EU Centre for Agricultural Technology (CECAT), 15-20 January, Beijing. Paper published in Proceedings of the International Seminar on Women in Agriculture and their Participation in the Development and Use of Agricultural Technologies. 1995. Beijing, China: China-European Union Centre for Agricultural Technology (CECAT).

- 1994. Gawai Matah Tangkai Padi, an Iban Indigenous Ritual Related to Hill Rice Farming. Celebration Held in Conjunction with International Women's Day, Rumah Jali Longhouse, Maong-Machan, 7-9 March, Sarawak, Malaysia. Feature article "Gawai Tuah Menoa Bansa Asal" in The Borneo Sun, Kuching, 20-21 December 1994. 